\title{
Chemical and physical properties of carbonated HA affect breast cancer cell behavior
}

\author{
Siyoung Choi ${ }^{1}$, Scott Coonrod $^{2}$, Lara Estroff ${ }^{3,4, *}$, Claudia Fischbach ${ }^{1,4, *}$
}

Affiliations: ${ }^{1}$ Department of Biomedical Engineering, ${ }^{2}$ Baker Institute for Animal Health, ${ }^{3}$ Department of Materials Science and Engineering, ${ }^{4}$ Kavli Institute at Cornell for Nanoscale Science, Cornell University, Ithaca, New York, 14853, USA.

*To whom correspondence should be addressed:

Claudia Fischbach

Department of Biomedical Engineering

Cornell University

157 Weill Hall

Ithaca, NY 14853

$+1(607) 255-4547$

+1 (607) 255-7330 (fax)

Email: cf99@cornell.edu

Lara Estroff

Department of Materials Science and Engineering

Cornell University

214 Bard Hall

Ithaca, NY 14853

$+1(607) 254-5256$

+1 (607) 255-2365

Email: cf99@cornell.edu

Submitted to: Acta Biomaterialia 


\begin{abstract}
Breast microcalcifications are routinely explored for mammographic detection of breast cancer and primarily composed of non-stoichiometric hydroxyapatite $\left(\mathrm{Ca}_{10-\mathrm{x}}\left(\mathrm{PO}_{4}\right)_{6-\mathrm{x}}\left(\mathrm{CO}_{3}\right)_{\mathrm{x}}(\mathrm{OH})_{2-\mathrm{x}}\right)$ (HA). Interestingly, HA morphology and carbonate substitution vary in malignant vs. benign lesions. However, whether or not these changes (i) are functionally linked and (ii) impact malignancy remains unclear due in part to a lack of model systems that permit evaluating these possibilities. Here, we have adapted a 96 well-based mineralized culture platform to investigate breast cancer cell behavior in response to systematic changes in the chemical and physical properties of HA. By adjusting the carbonate content of the simulated body fluid (SBF) solutions used during growth, we can control the morphology and carbonate substitution of the deposited HA. Our results suggest that both the combined and individual effects of these differences alter breast cancer cell growth and secretion of tumorigenic interleukin-8 (IL8). Consequently, changes in both HA carbonate incorporation and morphology impact the behavior of breast cancer cells. Collectively, our data underline the importance of biomineralized culture platforms to evaluate the functional contribution of HA materials properties to the pathogenesis of breast cancer.
\end{abstract}

Keywords: Microcalcifications, Hydroxyapatite, Breast cancer malignancy, Carbonate contents, Culture platform 


\section{Introduction}

Breast tissue microcalcifications serve as an indicator for non-palpable breast cancer during routine mammographical screening and are a common index for in situ and many invasive ductal carcinomas (e.g., primarily estrogen receptor [ER] and HER-2 positive; infrequently triple negative; rarely invasive lobular) $[1,2]$. Moreover, not only the pure presence of breast microcalcifications, but also their specific materials properties, matter with regards to clinical outcome. For example, the morphology of microcalcifications serves as an indicator for the malignant nature of mammographically detected lesions where crushed stone or casting-type microcalcifications are associated with a higher histopathological grade relative to diffusive punctate or powderish microcalcifications [3]. Furthermore, microcalcifications associated with malignant breast tissue are primarily composed of carbonated hydroxyapatite (HA), and the carbonate content of HA decreases with progression from benign to malignant disease $[4,5]$. Whether the morphologic differences and the carbonate content of HA are functionally coupled, and if these differences modulate tumor cell behavior individually and/or in a combined manner, remains largely unclear. To investigate this possible functional relationship a cell culture platform is needed that readily allows studying tumor cell behavior in response to HA with systematically varying carbonate content and morphological variations.

To understand and mimic the structure and function of biological HA, various synthetic methods have been developed. In particular, simulated body fluid (SBF) has been used to mineralize biomaterial surfaces for studies of mineral growth and cell-mineral interactions [6-9]. SBF contains inorganic ions found in human blood plasma, enables mineral deposition under near physiological conditions, and the chemical composition of the resultant HA resembles that of human bone $[10,11]$. Furthermore, SBF formulation, $\mathrm{pH}$, and temperature can be used to readily adjust the resulting HA properties [12-14]. For example, modifying the ion composition and concentration of SBF modulates the structure of HA surfaces and ultimately cell behavior $[6,15,16]$. In addition, varying the carbonate concentration of SBF regulates HA particle size and crystallinity [17], and these changes can modify cell functions as 
demonstrated in the context of non-viral gene delivery [18]. Yet no SBF-based mineralization methods currently exist that permit studying the relationship of HA surface properties, carbonate content, and tumor cell properties.

We have previously shown that HA broadly affects breast cancer cell growth and secretion of the chemokine interleukin-8 (IL-8) [19] and that this cellular response varies with defined HA nanoparticle characteristics [20]. IL-8 is of particular interest as elevated levels of this chemotactic and inflammatory chemokine have been linked to various aspects of malignancy including increased tumor angiogenesis, invasion, and bone-metastatic capability of breast cancer [21, 22]. For example, the more invasive character of estrogen (ER) negative vs. ER positive breast cancer cells is related to increased levels of IL8 [23]. Furthermore, bone-metastatic breast cancer cells express more IL-8 relative to lung-metastatic ones [24], and varied integrin engagement may underlie these changes [25]. Interestingly, altered IL-8 secretion in response to changes in HA materials properties may also be due to varied integrin engagement as HA materials properties influence the adsorption of proteins in general [26, 27] and adhesion molecules in particular [20]. Nevertheless, the effect of varied HA carbonate content and consequential changes in HA morphology on protein adsorption, tumor cell growth, and IL-8 secretion continues to be relatively poorly understood.

Here, we have adapted a previously developed mineralized culture platform [6] to systematically vary HA carbonate content and probed the resulting effects on HA morphology and the malignant potential of breast cancer cells. Our results revealed that varying the carbonate content of SBF may be used to generate HA coatings with defined surface properties and that the chemical and physical properties of these coatings correspond to the level of carbonate incorporation in HA. Importantly, the malignant potential of breast cancer cells correlates with changes in mineral properties implying that our approach may be useful to assess the relevance of HA mineral properties to breast cancer progression. 


\section{Materials and Methods}

\section{Mineral coating formation}

Poly(D,L-lactide-co-glycolide) (PLG, lactide : glycolide $=85: 15$, inherent viscosity: $0.6-0.8 \mathrm{dL} / \mathrm{g}$ in chloroform, Lakeshore Biomaterials) was coated on polypropylene 96-well plates by solvent casting of $100 \mathrm{mg} / \mathrm{mL}$ PLG in acetone. To accelerate mineral formation PLG-coated plates were hydrolyzed for 30 $\min$ in $0.5 \mathrm{M} \mathrm{NaOH}$ leading to the formation of carboxylate and hydroxyl groups at the surface (Fig. 1). For mineral formation, a series of modified simulated body fluid (mSBF) solutions was prepared (Table 1). All mSBF solutions contained twice as much $\mathrm{Ca}^{2+}$ and $\mathrm{PO}_{4}{ }^{3-}$ than conventional $\mathrm{SBF}$, which was first introduced by Kobubo and contains $\mathrm{Ca}^{2+}$ and $\mathrm{PO}_{4}{ }^{3-}$ concentrations similar to those found in human blood plasma [28] while all other components (except carbonate) were dissolved at the same concentration as in conventional SBF; carbonate concentrations ranged from $0 \mathrm{mM}$ to $27 \mathrm{mM}$. It should be noted that the term "carbonate" refers to both bicarbonate $\left(\mathrm{HCO}_{3}{ }^{-}\right)$and carbonate $\left(\mathrm{CO}_{3}{ }^{2-}\right)$ ions from added sodium bicarbonate because both species co-exist at $\mathrm{pH} 6.8$ in mSBF conditions. The $\mathrm{pH}$ of $\mathrm{mSBF}$ solutions was adjusted to $\mathrm{pH} 6.8$ ensuring mineral formation. To initiate mineralization of the hydrolyzed PLG surfaces a precursor mineral layer was formed by incubation in $4.2 \mathrm{mM}$ carbonate-containing $\mathrm{mSBF}$ for 4 days at $37{ }^{\circ} \mathrm{C}$ (Fig. 1). Subsequently, this solution was exchanged for $\mathrm{mSBF}$ with 0-27 mM carbonate for 4 days at $37{ }^{\circ} \mathrm{C}$. All solutions were refreshed every 12 hours during the course of mineral formation. Finally, mineral-coated surfaces were rinsed in deionized water and either dried for characterization of mineral properties or immediately used for cell culture.

\section{Mineral coating characterization}

The morphology of the mineral coatings was analyzed by scanning electron microscopy (SEM) (Tescan, Mira3 LM) following sputter coating with gold/palladium alloy (Denton Vacuum, Desk II). SEM images were taken at $5 \mathrm{keV}$. To characterize their structure and composition, mineral coatings were scraped off the PLG surface. Then, mineral coatings were ground and compressed with potassium bromide $(\mathrm{KBr})$ and 
the resulting pellets were analyzed using a Fourier transform infrared (FT-IR) spectrometer (Bruker, Hyperion 2000/Tensor 27). FT-IR spectra were measured in the range $400-2000 \mathrm{~cm}^{-1}$ and used to calculate relative carbonate composition and crystallinity as denoted in Fig. 2. The phases of intact mineral coatings were analyzed using X-ray diffractometry (XRD) (Bruker, D8 Discover-GADDS) after their removal from the PLG surfaces and mounting on a silicon wafer. XRD spectra were recorded in the range $2 \theta=2-50^{\circ}$. For comparison, FT-IR and XRD analysis was performed with commercially available HA nanoparticles (Sigma). Topographical features were examined using atomic force microscopy (AFM) (Asylum Research, MFP-3D-BIO) in air and in tapping mode. Surface roughness and area of the mineral coatings were analyzed after taking images at 3 representative locations $(5 \mu \mathrm{m}$ by $5 \mu \mathrm{m})$ for each condition using the AFM data analysis software Gwyddion.

\section{Analysis of serum protein adsorption on mineral coatings}

Mineral coatings were incubated in $\alpha$-Minimum Essential Medium ( $\alpha$-MEM) (Sigma-Aldrich) media containing $10 \%$ fetal bovine serum (FBS, Tissue Culture Biologicals) and 1\% penicillin/streptomycin (P/S, Gibco) for 1 hour and washed twice with PBS. For subsequent analysis of adsorbed serum proteins, mineral coatings were incubated in RIPA lysis buffer (Promega) and protein concentration in the supernatant was measured using a micro BCA kit (Pierce) according to manufacturer's instructions.

\section{Cell culture}

Human MDA-MB231(ATCC: HTB-26) and MCF7 (ATCC: HTB-22) cells were grown in $\alpha$-MEM media supplemented with $10 \% \mathrm{FBS}$ and $1 \% \mathrm{P} / \mathrm{S}$ at $37{ }^{\circ} \mathrm{C}$ and $5 \% \mathrm{CO}_{2}$ with refreshing media every 48 hours. A series of MCF10 cell lines including normal MCF10A (ATCC: CRL-10317), pre-malignant MCF10AT1 and malignant MCF10DCIS.com (both from Karmanos Cancer Institute) were grown in DMEM/F12 solution with $5 \%$ horse serum, $1 \% \mathrm{P} / \mathrm{S}$, supplemented with $20 \mathrm{ng} / \mathrm{mL}$ EGF, $0.5 \mu \mathrm{g} / \mathrm{mL}$ hydrocortisone, $100 \mathrm{ng} / \mathrm{mL}$ cholera toxin and $10 \mu \mathrm{g} / \mathrm{mL}$ insulin by refreshing media every 36 hours. At $80 \%$ confluence, cells were detached using trypsin-EDTA and seeded on mineral coatings. 


\section{Analysis of cell adhesion on mineral coatings}

For SEM imaging, 40,000 MDA-MB231 were seeded onto mineral coatings and incubated for 3 hours. After washing twice with PBS, samples were dehydrated in a series of ethanol solutions ranging from $25 \%$ to $100 \%$, treated with hexamethyldisilazane (HMDS) (Electron Microscopy Sciences) for $10 \mathrm{~min}$, and dried in a chemical hood. Finally, these prepared samples were coated with gold/palladium alloy and SEM images were taken as described above. To quantify cell adhesion, 40,000 cells/per well were seeded onto the different mineral coatings and maintained for 1 hour. Following PBS washes to remove nonadhered cells, adherent cells were lysed in Caron's buffer at the indicated time points; DNA concentrations in the lysates were measured using a QuantiFluor dsDNA kit (Promega) according to manufacturer's instructions. To assess the effect of specific integrins on cell adhesion, cell suspensions were incubated with $10 \mu \mathrm{g} / \mathrm{mL}$ of monoclonal antibody against human $\alpha_{\mathrm{v}}$ or $\beta_{1}$ integrin subunits (both from Millipore) in serum-free media for $30 \mathrm{~min}$ at $37{ }^{\circ} \mathrm{C}$ prior to seeding onto mineral coatings that were pre-adsorbed with serum proteins. Cell suspensions incubated without antibody served as controls. Quantification of adhered cells was performed as described above via determining DNA content.

\section{IL-8 secretion and growth of cells on mineral coatings}

10,000 cells were seeded onto mineral coatings and cultured for 2 days after which cell culture media was refreshed and collected 24 hours later. For measurement of growth, cells were cultured for 3 days, lysed in Caron's buffer and DNA concentration measured fluorimetrically using the aforementioned procedure. A commercial IL-8 ELISA kit (R\&D systems) was utilized to measure IL-8 content in the collected media; the amount of IL-8 was converted using standard curves and normalized to DNA concentration.

\section{Statistical analysis}

All quantitative tests were carried out in triplicate or higher $(n \geq 3)$ and all experiments were independently repeated at least twice. Data are expressed as mean \pm standard deviation and statistical significance $(P<0.05)$ was analyzed by One-way ANOVA with Tukey's post test using SPSS software. 


\section{Results and discussion}

\subsection{Carbonate concentration of $\mathrm{mSBF}$ regulates carbonate content in HA mineral coatings}

SBF solutions have been widely used to generate HA with well-defined materials properties for biological and engineering applications. For example, several studies demonstrated that altering SBF ion composition and concentration permits controlling the specific physical and chemical properties of HA [6, $16,17]$. We have adapted this approach and adjusted the composition of SBF in a manner that allowed us to develop HA of varying carbonate content. More specifically, we formulated mSBF solutions that contained twice as much $\mathrm{Ca}^{2+}$ and $\mathrm{PO}_{4}{ }^{3-}$ than conventional $\mathrm{SBF}$ and carbonate concentrations ranging from $0 \mathrm{mM}$ to $27 \mathrm{mM}$ (Table 1). Indeed, mineral coatings formed with these $\mathrm{mSBF}$ solutions consisted of carbonated HA phases (Fig. 2a). XRD analysis confirmed that all mineral coatings contained HA with two dominant diffraction peaks at $26^{\circ}$ and $32^{\circ}$ corresponding to the (002) plane at $26^{\circ}$ and (211), (112), and (300) planes at $32^{\circ}$. Importantly, for all conditions, peak broadening relative to commercial, highlycrystalline HA suggested that carbonate incorporation resulted in decreased crystallinity.

Next, FT-IR spectroscopy was used to determine the chemical structure and composition of the series of HA coatings in order to confirm that mSBF composition indeed controls carbonate substitution during mineral formation. The resulting FT-IR spectra contained peaks characteristic of phosphate groups (between $563 \mathrm{~cm}^{-1}$ and $601 \mathrm{~cm}^{-1}$ and between $1037 \mathrm{~cm}^{-1}$ and $1107 \mathrm{~cm}^{-1}$ ), hydrogen phosphate groups (at $970 \mathrm{~cm}^{-1}$ ), and carbonate groups (at $874 \mathrm{~cm}^{-1}$ and around $1460 \mathrm{~cm}^{-1}$ ) (Fig. 2b). Corresponding to an increased substitution of phosphate and/or hydroxyl anions by carbonate ions, the carbonate peak areas increased with increasing carbonate concentrations in mSBF solutions, while phosphate peaks broadened due to the elevated disorder of the phosphate ions within HA [29, 30]. Furthermore, the relative carbonate composition of HA mineral coatings was proportional to the carbonate concentrations of $\mathrm{mSBF}$ and higher than that of commercially available HA, as determined by calculating the ratio of the carbonate 
peak area at $874 \mathrm{~cm}^{-1}$ and phosphate peak area between $563 \mathrm{~cm}^{-1}$ and $601 \mathrm{~cm}^{-1}$ (Fig. 2c). Together, these results indicate that varying the composition of mSBF can modulate the carbonate content of HA.

Previous work has indicated that HA in breast microcalcifications contains approximately $0.2-3$ wt.\% carbonate, while HA in human bone is composed of 6-7 wt.\% carbonate $[4,31]$. While we did not directly determine carbonate content in this study, we performed comparisons with commercially available HA, a material frequently used to mimic stoichiometric HA. The relative carbonate composition of mineral coatings formed in the presence of $0 \mathrm{mM}$ carbonate was similar to commercially available HA, while mineral coatings formed with $27 \mathrm{mM}$ carbonate contained approximately 5 times more carbonate (Fig. 2c). This change of carbonate composition also affected the crystallinity of HA mineral coatings: Comparison of crystallinity indices, which were calculated by dividing the sum of FT-IR peaks representing O-P-O bending of phosphate in HA (between $563 \mathrm{~cm}^{-1}$ and $601 \mathrm{~cm}^{-1}$ ) by the height of the valley between them [32], revealed that HA crystallinity decreased with increasing carbonate incorporation corresponding to greater crystalline disorder (Fig. 2d). This inverse relationship between carbonate incorporation and crystallinity is consistent with a previous study demonstrating that the concentration of carbonate ions in SBF solutions regulates HA crystal size [17]. Collectively, these results indicate that carbonate composition and crystallinity can be controlled by carbonate concentrations in mSBF solutions.

\subsection{Carbonate incorporation modulates the surface properties of mineral coatings}

Previous studies suggest that varied SBF conditions can affect HA-surface topography [6, 16, 33]. To evaluate whether carbonate incorporation modulates the topography of our different HA mineral coatings, SEM analysis was performed. Low magnification images demonstrated that all conditions resulted in the formation of a continuous mineral layer after 4 days of incubation in the various mSBFs (Fig. 3A-H). At higher magnifications, it became apparent that the microstructure of the HA coatings changed as a function of the utilized carbonate concentrations (Fig. 3a-h). Coatings formed in the absence of carbonate 
exhibited a plate-like microstructure (Fig. 3a), whereas increasing mSBF carbonate concentration gradually decreased the size of the plate features and led to the formation of spherulitic microstructures (Fig. 3b-3g). This change in microstructure can be attributed to increased disorder of HA crystals due to carbonate incorporation. AFM surface topography images confirmed that the microstructure of the HA coatings changed systematically as a function of carbonate incorporation (Fig. 4a). Analysis of surface roughness furthermore confirmed that HA mineral coatings formed with $0 \mathrm{mM}$ carbonate were significantly rougher as compared to all other conditions, and that increasing carbonate content reduced surface roughness (Fig. 4b). Specifically, clear differences in surface roughness were detected between HA mineral coatings formed in $0 \mathrm{mM}$ and $2 \mathrm{mM}$ carbonate $\mathrm{mSBF}$ and $\mathrm{HA}$ mineral coatings formed with $4.2 \mathrm{mM}-15 \mathrm{mM}$ carbonate $\mathrm{mSBF}$. Interestingly, surface roughness of coatings seemed to increase when formed with $27 \mathrm{mM}$ carbonate $\mathrm{mSBF}$. However, this difference could be attributed to smaller spherulitic grain size (Fig. 4a) because surface roughness was similarly reduced when analysis was done on regions that were smaller than single spherulitic grains $(59 \pm 18 \mathrm{~nm}$, scan area: $1 \mu \mathrm{m} \times 1 \mu \mathrm{m})$. Corresponding to the change in surface roughness, carbonate incorporation also influenced the surface area of HA mineral coatings (Fig. 4c). The surface area of HA mineral coatings formed in $0 \mathrm{mM}$ and $2 \mathrm{mM}$ carbonate was increased relative to the other mineral coatings, while no significant difference was detected between coatings formed with $4.2-27 \mathrm{mM}$ carbonate.

Taken together, these results suggest that mSBF-mediated changes of HA carbonate incorporation can be used to vary the microstructure of HA mineral coatings with consequences on surface roughness and area. More broadly, our results indicate that carbonate content may directly contribute to the specific morphologies of malignant breast microcalcifications. It has to be noted, however, that the complexity of conditions regulating crystal growth in vivo is significant and not properly reflected in our system. Hence, future studies will be needed to further evaluate this connection.

\subsection{Changes in mineral properties alter protein adsorption and breast cancer cell adhesion.}


Cellular response to HA is mediated in part by differential protein adsorption [34-36]. To evaluate whether carbonate substitution affects protein adsorption, we quantified the amount of adsorbed proteins following incubation of the different HA mineral coatings in serum containing media. According to previous results, the presence of HA promoted protein adsorption relative to PLG control surfaces due to the increased hydrophilicity of HA (Fig. 5a). Interestingly, no difference in protein adsorption was detected among HA coatings formed with $0,6,10,15$, or $27 \mathrm{mM}$ mSBF. However, coatings formed with 2 and $4.2 \mathrm{mM} \mathrm{mSBF}$ adsorbed significantly more protein relative to all other conditions (Fig. 5a). A similar trend was noted when the amount of adsorbed protein was normalized to surface area (Suppl. Fig. 1). Previous studies indicated that the binding of biological molecules is influenced by the physical and chemical properties of HA including crystallinity, surface area, surface charge, and ion incorporation [26, 37-40]. For example, the reduction of HA crystal size due to carbonate incorporation can decrease the adsorption of bovine serum albumin [27]. Furthermore, alteration of composition due to substitution of ions in HA can modulate protein adsorption depending on the type of substituted ions [41, 42]. Our results correlate with these findings: HA mineral coatings formed with $4.2 \mathrm{mM}-27 \mathrm{mM}$ carbonate mSBF exhibited reduced crystallinity due to carbonate incorporation (Fig. 2c, d) and correspondingly decreased serum protein adsorption. Surface area remained unchanged among conditions and, therefore, was unlikely to affect protein adsorption (Fig. 4c). The inverse trend in protein adsorption on HA mineral coatings formed with $0 \mathrm{mM}$ vs. $2 \mathrm{mM}$ carbonate $\mathrm{mSBF}$ (i.e., increased protein adsorption with decreasing crystallinity and surface area) may be explained by the increased specific surface area due to reduced pore size which could enhance the available area for protein binding (Suppl. Fig. 2). Consequently, both chemical and physical properties of the varied mineral coatings influence the extent of serum protein adsorption.

To evaluate whether the detected differences in protein adsorption influence tumor cell adhesion, MDAMB231 breast cancer cells were seeded onto the different surfaces and their number and morphologies were analyzed. In general, mineralized surfaces enhanced cell attachment as compared to non-mineralized 
PLG control surfaces even though cells on the latter tended to spread more as indicated by the wider distribution of single data points (Fig. 5b, c, Suppl. Fig. 3). This result can be attributed to the increased adsorption of adhesive proteins on mineral surfaces as suggested by previous studies [20, 36] (Fig. 5a). Nevertheless, the extent of cell adhesion on the different HA mineral coatings did not directly correlate with the amount of adsorbed serum proteins. More specifically, cell adhesion was significantly enhanced on HA coatings formed in $2 \mathrm{mM}$ vs. $4.2 \mathrm{mM}$ mSBF although both coatings adsorbed similar amounts of serum proteins. On the other hand, HA mineral coatings formed in $0 \mathrm{mM} \mathrm{mSBF}$ promoted cell adhesion relative to HA mineral coatings formed in $10-17 \mathrm{mM} \mathrm{mSBF}$ although protein adsorption was similar on all coatings. Consequently, cellular responses on the different surfaces were not simply regulated by the amount of adsorbed proteins, but other surface characteristics also played a role. In particular, HA surface roughness and area may be critical because MDA-MB231 cell adhesion was highest on HA mineral coatings formed in $0 \mathrm{mM}$ and $2 \mathrm{mM} \mathrm{mSBF}$ relative to $\mathrm{HA}$ mineral coatings with decreased surface roughness and area (i.e., coatings formed in 4.2-27 $\mathrm{mM} \mathrm{mSBF)} \mathrm{(Fig.} \mathrm{5b).} \mathrm{This} \mathrm{result} \mathrm{is} \mathrm{in} \mathrm{agreement} \mathrm{with}$ previous studies indicating that surface roughness of HA regulates cell adhesion [43] and subsequent cellular activity [44]. Furthermore, surface chemistry can impact the bioactivity of selectively adsorbed proteins and thereby influence cellular behavior. Fibronectin is particularly relevant as it regulates malignancy and is differentially adsorbed onto HA as a function of varied materials properties [20]. In addition, HA-adsorbed fibronectin can undergo conformational changes thereby regulating integrin specificity [37, 45]. More specifically, unfolding of fibronectin enhances the distance between RGDbinding and PHSRN synergy sites $[46,47]$. This decreases binding specificity of $\alpha_{5} \beta_{1}$ integrins while enhancing engagement of non-synergy-dependent integrins (such as $\alpha_{v} \beta_{3}$ integrins), with potential implications for cellular signaling [48].

To determine whether HA-dependent differences in cell adhesion were related to varied binding of $\alpha_{5} \beta_{1}$ vs. $\alpha_{v} \beta_{3}$, adhesion experiments were repeated in which binding via these integrins was inhibited with $\alpha_{\mathrm{v}}$ and $\beta_{1}$ function-blocking antibodies. Surprisingly, this treatment only affected adhesion on non- 
mineralized PLG surfaces, whereas no significant difference was detected on HA mineral coatings indicating that integrins composed of $\alpha_{\mathrm{v}}$ and $\beta_{1}$-subunits are not responsible for differences in breast cancer cell adhesion on the different mineral surfaces (Fig. 6). Clearly, many other cell surface proteins can be involved in regulating cell-mineral interactions. For example, CD44, a transmembrane glycoprotein with binding domains for hyaluronan, osteopontin, collagen, and fibronectin that also serves as a prognostic marker for breast cancer malignancy may play a role [49-51]. Future studies will need to evaluate the potential contribution of other cell surface receptors including CD44 to mineral-mediated differences in breast cancer cell behavior.

\subsection{Carbonate-dependent changes of HA surface properties affect breast cancer cell behavior}

To evaluate the relevance of carbonate-dependent changes of HA surface properties to breast cancer cell behavior, MDA-MB231 cells were cultured on the different mineral coatings for 3 days. Subsequently, their growth and secretion of pro-tumorigenic IL-8 were analyzed (Fig. 7). Generally, non-mineralized PLG stimulated cell growth as compared to HA mineral coatings (Fig. 7a), whereas an opposite effect was observed for IL-8 secretion (Fig. 7b). With regards to varied carbonate substitution, tumor cell growth and IL-8 secretion were also affected in an inverse manner. More specifically, cell growth was reduced on surfaces formed with 0-4.2 mM mSBF, but enhanced on coatings formed with 4.2-27 mM mSBF. In contrast, IL-8 secretion was increased on surfaces formed with $0 \mathrm{mM}-4.2 \mathrm{mM} \mathrm{mSBF}$, but decreased on coatings formed with 4.2-27 mM mSBF. This biphasic regulation is likely due to both topographical changes of the coatings $(0-4.2 \mathrm{mM})$ and varied crystallinity $(4.2-27 \mathrm{mM})$. In particular, a previous study suggests that greater micro/nanotopography of HA can enhance the proliferation of human bone marrow cells [43]. Accordingly, tumor cell growth was reduced on coatings with gradually decreasing surface roughness (i.e., which were formed with 0-4.2 mM mSBF) (Fig. 4b). Nevertheless, coatings with comparable surface roughness (i.e., which were formed with 4.2-27 mM mSBF) still stimulated cell growth suggesting that other intrinsic materials properties may play a role. For example, coatings formed with 4.2-27 mM mSBF exhibited reduced crystallinity (Fig. 4), which according to our 
previous results can stimulate tumor cell growth [20]. Reduced surface roughness and HA crystallinity may also be responsible for the observed changes in IL-8 secretion. In particular, rougher surfaces typically enhance the pro-inflammatory capacity of cells [52], while decreased HA crystallinity inhibits IL-8 secretion [53]. The inversely regulated changes in cell density are unlikely to be the primary driver of IL-8 secretion as enhanced cell-cell contact, 3-D tissue context, and elevated ECM deposition typically enhance IL-8 secretion $[25,54,55]$, while in our study greater cell density correlated with reduced IL-8 levels. On the other hand, it is possible that the detected increase in IL-8 secretion rather than direct effects of HA materials properties may have promoted cell growth [56, 57]. Yet siRNA-mediated suppression of IL-8 levels was previously shown not to affect estrogen receptor negative (ER-) cell proliferation and cell cycle phase distribution [58].

Another possible mechanism by which the different HA coatings may influence IL-8 secretion is their differential release of calcium ions. Dissolution of HA coatings can enhance calcium concentrations in the culture medium [6], which, for example, may activate calcium sensing receptors regulating cytokine and growth factor production [59]. Coatings with elevated carbonate content released more calcium, consistent with the known increase in solubility of carbonated apatite as compared to HA (Suppl. Fig. 4). Nevertheless, altered calcium release was not the primary driver of differential MDA-MB231 growth and IL-8 secretion on the different coatings because (i) the calcium release did not correspond with the detected cellular changes and (ii) supplementation of MDA-MB231 cultures with relevant levels of exogenous calcium did not alter MDA-MB231 growth and IL-8 secretion (Suppl. Fig. 5). Collectively, our results suggest that tumor cell behavior is regulated by HA surface properties and that carbonate substitution plays an important role in this process.

To confirm the relevance of our findings, we assessed the modulatory effect of HA carbonate substitution on additional breast cancer cell lines. First, we compared the more aggressive, highly metastatic MDAMB231 breast cancer cells with the more benign MCF7 cells. Mineral coatings formed in $0 \mathrm{mM}, 4.2 \mathrm{mM}$ and $15 \mathrm{mM} \mathrm{mSBF}$ were used for these studies as surface topography ( $0 \mathrm{mM}$ vs 4.2 and $15 \mathrm{mM})$ and 
carbonate composition/crystallinity $(4.2 \mathrm{mM}$ vs $15 \mathrm{mM})$ of these coatings distinctly regulated IL-8 secretion of MDA-MB231. Generally, MCF7 secreted significantly less IL-8 than MDA-MB231 on both non-mineralized and mineralized surfaces. These results are in agreement with previous studies showing that estrogen receptor positive (ER+) breast cancer cells such as MCF7 secrete less IL-8 relative to ERbreast cancer cells such as MDA-MB231. For example, Lin and et al, reported, that IL-8 secretion levels correlate with ER status in 11 human breast cancer cell lines whereby ER-cell lines exhibit significantly increased IL-8 levels [21]. Interestingly, exposure of MCF-7 to mineral upregulated IL-8 albeit at very modest levels relative to MDA-MB231. In particular, no significant difference was detected between coatings formed in 4.2 vs. $15 \mathrm{mM}$ mSBF suggesting that low HA carbonate content can enhance IL-8 secretion of MDA-MB231, but not MCF-7 cells, which may be due to their varied malignant potential. Importantly, the detected changes were due to cellular responses to the mineral coatings rather than to the underlying PLG surface as cells cultured on tissue culture polystyrene (TCPS) and PLG exhibited similar IL-8 secretion (Suppl. Fig. 6).

To test the relevance of these findings, we repeated our studies with 3 isogenically matched MCF10A cell lines of breast cancer progression. More specifically, normal (MCF10A), pre-malignant (MCF10AT1) and malignant (MCFDCIS.com) cells were seeded onto mineral coatings for comparison of IL-8 secretion. Interestingly, when plated on PLG control surfaces all 3 cell lines secreted comparable levels of IL-8 (MCF10A: $0.22 \pm 0.06$ pg/ng DNA, MCF10AT1: $0.07 \pm 0.03$ pg/ng DNA, MCFDCIS.com: $0.24 \pm 0.04$ pg/ng DNA). However, when plated onto the various mineral surfaces differences in IL-8 secretion became apparent. More specifically, MCF10AT1 only responded marginally to culture on mineral, while MCF10A and MCFDCIS significantly increased IL-8 secretion upon interactions with HA. Importantly, MCF10A increased IL-8 secretion relatively uniformly on all mineral coatings although the most pronounced effect was noticed for coatings formed with $0 \mathrm{mM} \mathrm{mSBF}$. MCFDCIS, on the other hand, upregulated IL-8 secretion relatively modestly on coatings formed with $0 \mathrm{mM} \mathrm{mSBF}$ and no difference was noted with $15 \mathrm{mM} \mathrm{mSBF}$ coatings; however, a very pronounced effect was observed when cells were 
seeded onto mineral surfaces formed with $4.2 \mathrm{mM}$ mSBF similar to MDA-MB231 cells. Together these findings suggest that carbonate content in HA can impact breast cancer cell behavior and may thus, help explain the previously described clinical correlation of decreased HA carbonate content and worse clinical prognosis. Future studies will need to evaluate the underlying mechanisms, and the developed HA culture platforms with systematically varying carbonate content will be critical to this end.

\section{Conclusion}

The effect of carbonated HA on breast cancer cell behavior was studied using apatite coatings of varying carbonate concentration. Enhanced carbonate incorporation linearly decreased crystallinity of the mineral coatings while reducing surface roughness suggesting that carbonate content may be linked to the specific morphologies of radiographically detected breast microcalcifications. The integrated effects of these surface property changes regulated tumor cell adhesion, growth, and IL-8 secretion in a biphasic manner: surface topography changes seemed to be the primary driver of differential cell behavior on surfaces with low carbonate content, while surface chemistry appeared to regulate cell behavior on coatings with higher carbonate content. In the future, the developed culture models may be used to advance our mechanistical understanding of the role of HA materials properties in regulating tumor cell behavior in the presence of microcalcifications and during bone metastasis.

\section{Acknowledgment}

This work supported by NIH/NCI R01CA173083 and use of the Cornell Center for Materials Research Shared Facilities which is supported through the NSF MRSEC program (DMR-1120296). 


\section{References}

[1] Burnside ES, Ochsner JE, Fowler KJ, Fine JP, Salkowski LR, Rubin DL, et al. Use of Microcalcification Descriptors in BI-RADS 4th Edition to Stratify Risk of Malignancy. Radiology 2007;242:388-95.

[2] Ferranti C, Coopmans de Yoldi G, Biganzoli E, Bergonzi S, Mariani L, Scaperrotta G, et al. Relationships between age, mammographic features and pathological tumour characteristics in non-palpable breast cancer. The British Journal of Radiology 2000;73:698-705.

[3] Holmberg L, Wong YNS, Tabar L, Ringberg A, Karlsson P, Arnesson LG, et al. Mammography castingtype calcification and risk of local recurrence in DCIS: analyses from a randomised study. $\mathrm{Br} J$ Cancer 2013;108:812-9.

[4] Baker R, Rogers K, Shepherd N, Stone N. New relationships between breast microcalcifications and cancer. Brit J Cancer 2010;103:1034-9.

[5] Haka AS, Shafer-Peltier KE, Fitzmaurice M, Crowe J, Dasari RR, Feld MS. Identifying Microcalcifications in Benign and Malignant Breast Lesions by Probing Differences in Their Chemical Composition Using Raman Spectroscopy. Cancer Research 2002;62:5375-80.

[6] Choi S, Murphy WL. The effect of mineral coating morphology on mesenchymal stem cell attachment and expansion. Journal of Materials Chemistry 2012;22:25288-95.

[7] Juhasz J, Best S, Auffret A, Bonfield W. Biological control of apatite growth in simulated body fluid and human blood serum. Journal of Materials Science: Materials in Medicine 2008;19:1823-9.

[8] Murphy WL, Hsiong S, Richardson TP, Simmons CA, Mooney DJ. Effects of a bone-like mineral film on phenotype of adult human mesenchymal stem cells in vitro. Biomaterials 2005;26:303-10.

[9] Davis HE, Binder BYK, Schaecher P, Yakoobinsky DD, Bhat A, Leach JK. Enhancing Osteoconductivity of Fibrin Gels with Apatite-Coated Polymer Microspheres. Tissue Engineering Part A 2013;19:1773-82.

[10] Kokubo T. Formation of biologically active bone-like apatite on metals and polymers by a biomimetic process. Thermochimica Acta 1996;280-281:479-90.

[11] Li X, Chang J. Preparation of bone-like apatite-collagen nanocomposites by a biomimetic process with phosphorylated collagen. Journal of Biomedical Materials Research Part A 2008;85A:293-300.

[12] Jalota S, Bhaduri SB, Tas AC. Effect of carbonate content and buffer type on calcium phosphate formation in SBF solutions. Journal of Materials Science: Materials in Medicine 2006;17:697-707.

[13] Barrere F, van Blitterswijk CA, de Groot K, Layrolle P. Influence of ionic strength and carbonate on the Ca-P coating formation from SBF×5 solution. Biomaterials 2002;23:1921-30.

[14] Qu H, Wei $\mathrm{M}$. The effect of temperature and initial $\mathrm{pH}$ on biomimetic apatite coating. Journal of Biomedical Materials Research Part B: Applied Biomaterials 2008;87B:204-12.

[15] Chou Y-F, Huang W, Dunn JCY, Miller TA, Wu BM. The effect of biomimetic apatite structure on osteoblast viability, proliferation, and gene expression. Biomaterials 2005;26:285-95.

[16] Costa DO, Allo BA, Klassen R, Hutter JL, Dixon SJ, Rizkalla AS. Control of Surface Topography in Biomimetic Calcium Phosphate Coatings. Langmuir 2012;28:3871-80.

[17] Müller L, Müller FA. Preparation of SBF with different content and its influence on the composition of biomimetic apatites. Acta Biomaterialia 2006;2:181-9.

[18] Choi S, Yu X, Jongpaiboonkit L, Hollister SJ, Murphy WL. Inorganic coatings for optimized non-viral transfection of stem cells. Scientific Reports 2013;3:1567.

[19] Pathi SP, Kowalczewski C, Tadipatri R, Fischbach C. A Novel 3-D Mineralized Tumor Model to Study Breast Cancer Bone Metastasis. PLoS ONE 2010;5:e8849.

[20] Pathi SP, Lin DDW, Dorvee JR, Estroff LA, Fischbach C. Hydroxyapatite nanoparticle-containing scaffolds for the study of breast cancer bone metastasis. Biomaterials 2011;32:5112-22.

[21] Lin Y, Huang R, Chen L, Li S, Shi Q, Jordan C, et al. Identification of interleukin-8 as estrogen receptor-regulated factor involved in breast cancer invasion and angiogenesis by protein arrays. International Journal of Cancer 2004;109:507-15. 
[22] Kamalakar A, Bendre MS, Washam CL, Fowler TW, Carver A, Dilley JD, et al. Circulating interleukin-8 levels explain breast cancer osteolysis in mice and humans. Bone 2014;61:176-85.

[23] Freund A, Chauveau C, Brouillet J-P, Lucas A, Lacroix M, Licznar A, et al. IL-8 expression and its possible relationship with estrogen-receptor-negative status of breast cancer cells. Oncogene 2003;22:256-65.

[24] De Larco JE, Wuertz BRK, Rosner KA, Erickson SA, Gamache DE, Manivel JC, et al. A Potential Role for Interleukin-8 in the Metastatic Phenotype of Breast Carcinoma Cells. The American Journal of Pathology 2001;158:639-46.

[25] Fischbach C, Kong HJ, Hsiong SX, Evangelista MB, Yuen W, Mooney DJ. Cancer cell angiogenic capability is regulated by 3D culture and integrin engagement. Proceedings of the National Academy of Sciences 2009;106:399-404.

[26] Matsumoto T, Okazaki M, Inoue M, Yamaguchi S, Kusunose T, Toyonaga T, et al. Hydroxyapatite particles as a controlled release carrier of protein. Biomaterials 2004;25:3807-12.

[27] Takemoto S, Kusudo Y, Tsuru K, Hayakawa S, Osaka A, Takashima S. Selective protein adsorption and blood compatibility of hydroxy-carbonate apatites. Journal of Biomedical Materials Research Part A 2004;69A:544-51.

[28] Kokubo T, Kushitani H, Sakka S, Kitsugi T, Yamamuro T. Solutions able to reproduce in vivo surfacestructure changes in bioactive glass-ceramic A-W3. Journal of Biomedical Materials Research 1990;24:721-34.

[29] Pleshko N, Boskey A, Mendelsohn R. Novel infrared spectroscopic method for the determination of crystallinity of hydroxyapatite minerals. Biophysical Journal 1991;60:786-93.

[30] Fleet ME, Liu X. Coupled substitution of type A and B carbonate in sodium-bearing apatite. Biomaterials 2007;28:916-26.

[31] Ou-Yang H, Paschalis EP, Mayo WE, Boskey AL, Mendelsohn R. Infrared Microscopic Imaging of Bone: Spatial Distribution of CO32-. Journal of Bone and Mineral Research 2001;16:893-900.

[32] Weiner S, Bar-Yosef O. States of preservation of bones from prehistoric sites in the Near East: A survey. Journal of Archaeological Science 1990;17:187-96.

[33] Ban S, Maruno S. Morphology and microstructure of electrochemically deposited calcium phosphates in a modified simulated body fluid. Biomaterials 1998;19:1245-53.

[34] Sawyer AA, Hennessy KM, Bellis SL. Regulation of mesenchymal stem cell attachment and spreading on hydroxyapatite by RGD peptides and adsorbed serum proteins. Biomaterials 2005;26:1467-75.

[35] Lin K, Xia L, Gan J, Zhang Z, Chen H, Jiang X, et al. Tailoring the Nanostructured Surfaces of Hydroxyapatite Bioceramics to Promote Protein Adsorption, Osteoblast Growth, and Osteogenic Differentiation. ACS Applied Materials \& Interfaces 2013;5:8008-17.

[36] Kilpadi KL, Chang P-L, Bellis SL. Hydroxylapatite binds more serum proteins, purified integrins, and osteoblast precursor cells than titanium or steel. Journal of Biomedical Materials Research 2001;57:258-

67.

[37] Wu F, Lin DDW, Chang JH, Fischbach C, Estroff LA, Gourdon D. Effect of the Materials Properties of Hydroxyapatite Nanoparticles on Fibronectin Deposition and Conformation. Crystal Growth \& Design 2015;15:2452-60.

[38] Choi S, Murphy WL. Sustained plasmid DNA release from dissolving mineral coatings. Acta Biomaterialia 2010;6:3426-35.

[39] Fernández-Montes Moraleda B, Román JS, Rodríguez-Lorenzo LM. Influence of surface features of hydroxyapatite on the adsorption of proteins relevant to bone regeneration. Journal of Biomedical Materials Research Part A 2013;101A:2332-9.

[40] Yin G, Liu Z, Zhan J, Ding F, Yuan N. Impacts of the surface charge property on protein adsorption on hydroxyapatite. Chemical Engineering Journal 2002;87:181-6. 
[41] Fujii E, Ohkubo M, Tsuru K, Hayakawa S, Osaka A, Kawabata K, et al. Selective protein adsorption property and characterization of nano-crystalline zinc-containing hydroxyapatite. Acta Biomaterialia 2006;2:69-74.

[42] Yu X, Khalil A, Dang PN, Alsberg E, Murphy WL. Multilayered Inorganic Microparticles for Tunable Dual Growth Factor Delivery. Advanced Functional Materials 2014;24:3082-93.

[43] Deligianni DD, Katsala ND, Koutsoukos PG, Missirlis YF. Effect of surface roughness of hydroxyapatite on human bone marrow cell adhesion, proliferation, differentiation and detachment strength. Biomaterials 2000;22:87-96.

[44] Li X, van Blitterswijk CA, Feng $Q$, Cui F, Watari F. The effect of calcium phosphate microstructure on bone-related cells in vitro. Biomaterials 2008;29:3306-16.

[45] García AJ, Vega MaD, Boettiger D. Modulation of Cell Proliferation and Differentiation through Substrate-dependent Changes in Fibronectin Conformation. Molecular Biology of the Cell 1999;10:78598.

[46] Krammer A, Craig D, Thomas WE, Schulten K, Vogel V. A structural model for force regulated integrin binding to fibronectin's RGD-synergy site. Matrix Biology 2002;21:139-47.

[47] Altroff H, van der Walle CF, Asselin J, Fairless R, Campbell ID, Mardon HJ. The Eighth FIII Domain of Human Fibronectin Promotes Integrin $\alpha 5 \beta 1$ Binding via Stabilization of the Ninth FIII Domain. Journal of Biological Chemistry 2001;276:38885-92.

[48] Dolatshahi-Pirouz A, Jensen T, Foss M, Chevallier J, Besenbacher F. Enhanced Surface Activation of Fibronectin upon Adsorption on Hydroxyapatite. Langmuir 2009;25:2971-8.

[49] Sheridan C, Kishimoto H, Fuchs R, Mehrotra S, Bhat-Nakshatri P, Turner C, et al. CD44+/CD24breast cancer cells exhibit enhanced invasive properties: an early step necessary for metastasis. Breast Cancer Research 2006;8:R59.

[50] Culty M, Shizari M, Thompson EW, Underhill CB. Binding and degradation of hyaluronan by human breast cancer cell lines expressing different forms of CD44: Correlation with invasive potential. Journal of Cellular Physiology 1994;160:275-86.

[51] Ponta H, Sherman L, Herrlich PA. CD44: From adhesion molecules to signalling regulators. Nat Rev Mol Cell Biol 2003;4:33-45.

[52] Tan KS, Qian L, Rosado R, Flood PM, Cooper LF. The role of titanium surface topography on J774A.1 macrophage inflammatory cytokines and nitric oxide production. Biomaterials 2006;27:5170-7.

[53] Grandjean-Laquerriere A, Laquerriere P, Guenounou M, Laurent-Maquin D, Phillips TM. Importance of the surface area ratio on cytokines production by human monocytes in vitro induced by various hydroxyapatite particles. Biomaterials 2005;26:2361-9.

[54] Tan CP, Ri Seo B, Brooks DJ, Chandler EM, Craighead HG, Fischbach C. Parylene peel-off arrays to probe the role of cell-cell interactions in tumour angiogenesis. Integrative Biology 2009;1:587-94.

[55] Fischbach C, Chen R, Matsumoto T, Schmelzle T, Brugge JS, Polverini PJ, et al. Engineering tumors with 3D scaffolds. Nat Meth 2007;4:855-60.

[56] Arenberg DA, Kunkel SL, Polverini PJ, Glass M, Burdick MD, Strieter RM. Inhibition of interleukin-8 reduces tumorigenesis of human non-small cell lung cancer in SCID mice. The Journal of Clinical Investigation 1996;97:2792-802.

[57] Luppi F, Longo AM, de Boer WI, Rabe KF, Hiemstra PS. Interleukin-8 stimulates cell proliferation in non-small cell lung cancer through epidermal growth factor receptor transactivation. Lung Cancer 2007;56:25-33.

[58] Yao C, Lin Y, Chua M-S, Ye C-S, Bi J, Li W, et al. Interleukin-8 modulates growth and invasiveness of estrogen receptor-negative breast cancer cells. International Journal of Cancer 2007;121:1949-57.

[59] Hernández-Bedolla MA, Carretero-Ortega J, Valadez-Sánchez M, Vázquez-Prado J, Reyes-Cruz G. Chemotactic and proangiogenic role of calcium sensing receptor is linked to secretion of multiple 
cytokines and growth factors in breast cancer MDA-MB-231 cells. Biochimica et Biophysica Acta (BBA) Molecular Cell Research 2015;1853:166-82. 


\section{Figure legends}

Figure 1. Schematic of HA mineral formation procedure on 96-well polypropylene (PP) plates. According to previous work (Ref. 6) HA mineral growth was induced by coating 96-well PP plates with

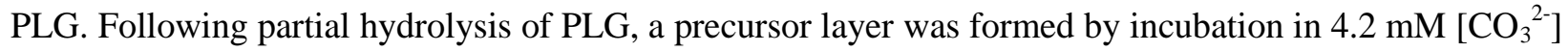
$\mathrm{mSBF}$ for 4 days. Finally, mineral coatings of varied carbonate content were formed by incubation in 0 $27 \mathrm{mM}\left[\mathrm{CO}_{3}{ }^{2-}\right] \mathrm{mSBF}$ for 4 days. Scale bar $=5 \mathrm{~mm}$.

Figure 2. Adjusting mSBF carbonate content alters the composition of HA mineral coatings. (a) XRD and (b) FT-IR spectra of commercially available HA (Sigma) and HA mineral coatings that were formed by incubation in 0-27 mM carbonate mSBF. (c) Relative carbonate composition of HA mineral coatings as determined by calculating the ratio of the $\mathrm{CO}_{3}{ }^{2-}$ and $\mathrm{PO}_{4}{ }^{3-}$ FT-IR peak areas at $874 \mathrm{~cm}^{-1}$ and $900-1300$ $\mathrm{cm}^{-1}$, respectively. (d) Crystallinity index was calculated from FT-IR peaks by dividing the sum of the peak maxima at $565 \mathrm{~cm}^{-1}$ and $603 \mathrm{~cm}^{-1}$ by the height of the valleys between them. ${ }^{*}$ and ${ }^{\#}$ indicate significant differences as compared to HA and $0 \mathrm{mM}$ conditions, respectively $(P<0.05)$.

Figure 3. Adjusting mSBF carbonate content alters the morphology of HA mineral coatings. Low (A-H) and high magnification (a-h) SEM micrographs captured after 8 days of mineral formation in 0-27 $\mathrm{mM}$ carbonate mSBF. Scale bar $=10 \mu \mathrm{m}(\mathrm{A}-\mathrm{H})$ and $0.5 \mu \mathrm{m}(\mathrm{a}-\mathrm{h})$. Non-hydrolyzed PLG control films are shown for comparison.

Figure 4. Adjusting mSBF carbonate content modulates the surface properties of HA mineral coatings. (a) Representative AFM micrographs of HA mineral coatings and non-hydrolyzed PLG control surfaces as collected in tapping mode. (b) Surface roughness and (c) Surface area of HA mineral coatings as determined by image analysis of representative $5 \mu \mathrm{m}$ x $5 \mu \mathrm{m}$ regions. Upper case letter (A) indicates significant difference relative to PLG. Lower case letters ( $a, b$ and $c)$ indicate significant differences relative to $0 \mathrm{mM}, 2 \mathrm{mM}$ and $4.2 \mathrm{mM}$ conditions, respectively $(\mathrm{P}<0.05)$. Scale bar $=1 \mu \mathrm{m}$.

Figure 5. Adjusting mSBF carbonate content during mineral formation regulates subsequent serum protein adsorption and MDA-MB231 cell adhesion. (a) Serum protein adsorption on HA mineral coatings after 1 hour of incubation in serum-containing media as determined by colorimetric analysis. (b) DNA concentration of lysates prepared from adherent MDA-MB231 1 hour after seeding on mineral coatings as measured fluorimetrically. (c) Representative SEM images of MDA-MB231 cells 3 hours after seeding on mineral coatings. Arrows indicate elongated cells. Upper case letter (A) indicates significant difference relative to PLG. Lower case letters ( $\mathrm{a}, \mathrm{b}$ and $\mathrm{c}$ ) indicate significant differences relative to $0 \mathrm{mM}, 2 \mathrm{mM}$ and $4.2 \mathrm{mM}$ conditions, respectively $(\mathrm{P}<0.05)$. Scale bar $=20 \mu \mathrm{m}$.

Figure 6. $\alpha_{\mathrm{v}}$ and $\beta_{1}$ integrins regulate breast cancer cell adhesion on PLG surfaces, but not HA mineral coatings. DNA concentration of lysates prepared from adherent MDA-MB231 1 hour after seeding on mineral coatings in the presence and absence of function-blocking (a) $\alpha_{v}$ or (b) $\beta_{1}$-integrin antibodies as measured fluorimetrically. * indicates significant differences between antibody $\left(\alpha_{v}, \beta_{1}\right)$ and control (No ab) conditions $(P<0.05)$.

Figure 7. HA mineral properties regulate MDA-MB231 growth and IL-8 secretion. MDA-MB231 (a) growth and (b) IL-8 secretion 3 days after seeding onto the different HA and PLG control surfaces as 
analyzed by fluorimetric quantification of DNA content and ELISA of conditioned media, respectively. Dashed lines indicate a biphasic regulation of cell behavior that is likely due to topographical (0-2 $\mathrm{mM})$ vs. chemical (4.2-27 $\mathrm{mM}$ ) differences of the resulting mineral coatings. Upper case letter (A) indicates significant difference relative to PLG. Lower case letters ( $a, b$ and $c)$ indicate significant differences relative to $0 \mathrm{mM}, 2 \mathrm{mM}$ and $4.2 \mathrm{mM}$ conditions, respectively $(\mathrm{P}<0.05)$.

Figure 8. HA mineral properties differentially affect IL-8 secretion of various breast cancer cell lines. IL8 secretion of (a) MCF7 vs. MDA-MB231 as well as of (b) normal MCF10A vs. pre-malignant MCF10AT1 vs. malignant MCF10DCIS.com as determined by ELISA followed by normalization to DNA content after 3 days of culture on the different mineral coatings. Upper case letter (A) indicates significant difference relative to PLG. Lower case letters ( $a, b$ and $c)$ indicate significant differences relative to $0 \mathrm{mM}, 4.2 \mathrm{mM}$ and $15 \mathrm{mM}$ conditions, respectively $(\mathrm{P}<0.05)$. 


\section{Surface treatment}

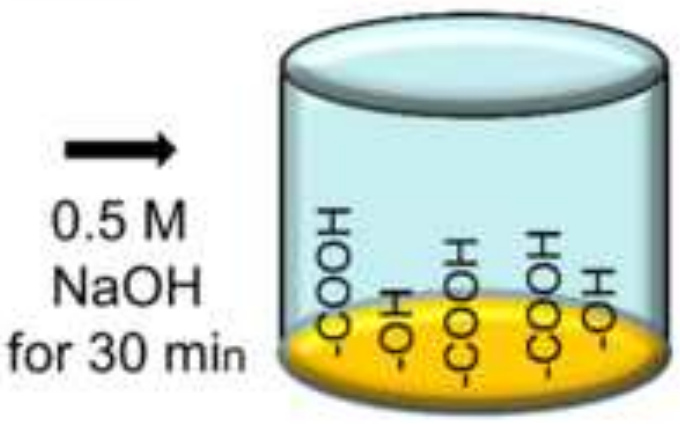

(2) Hydrolysis of PLG surfaces

\section{Precursor layer formation}

$\mathrm{mSBF}$ with $4.2 \mathrm{mM}$ carbonate at $37^{\circ} \mathrm{C}$ for 4 days

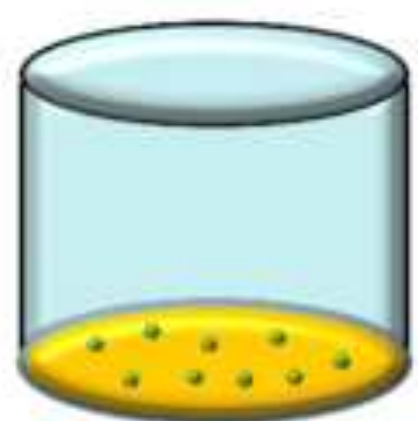

(4) Surface nucleation

\section{Mineral coating formation}

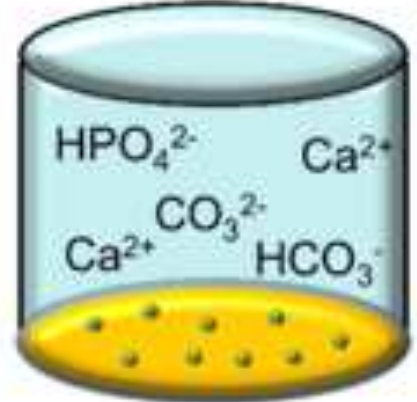

mSBF with $0-27 \mathrm{mM}$ carbonate at $37^{\circ} \mathrm{C}$ for 4 days

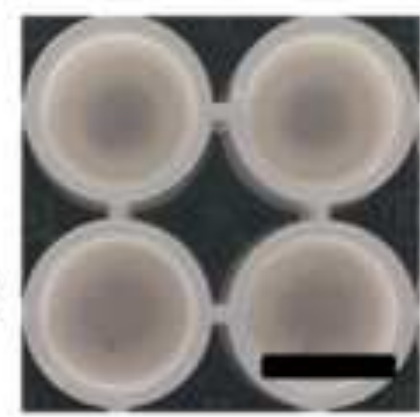

(6) Mineral growth

\section{Mineral coating formation}

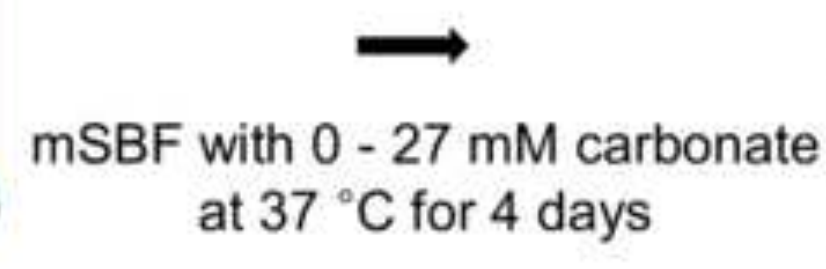

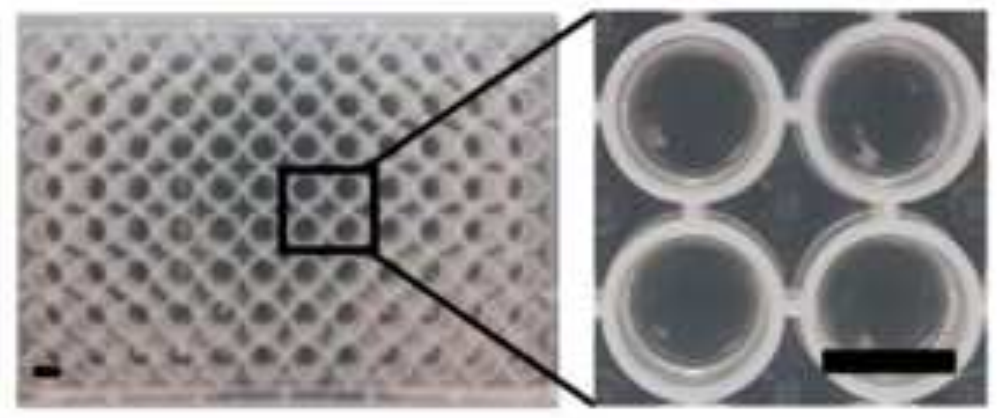

(1) PLG coating on 96-well plate

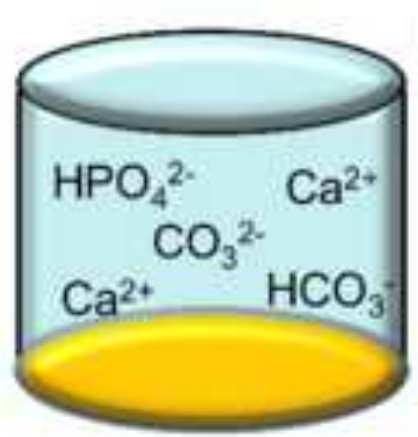

(3) Incubation in mSBF
(5) Incubation in mSBF 
(a)

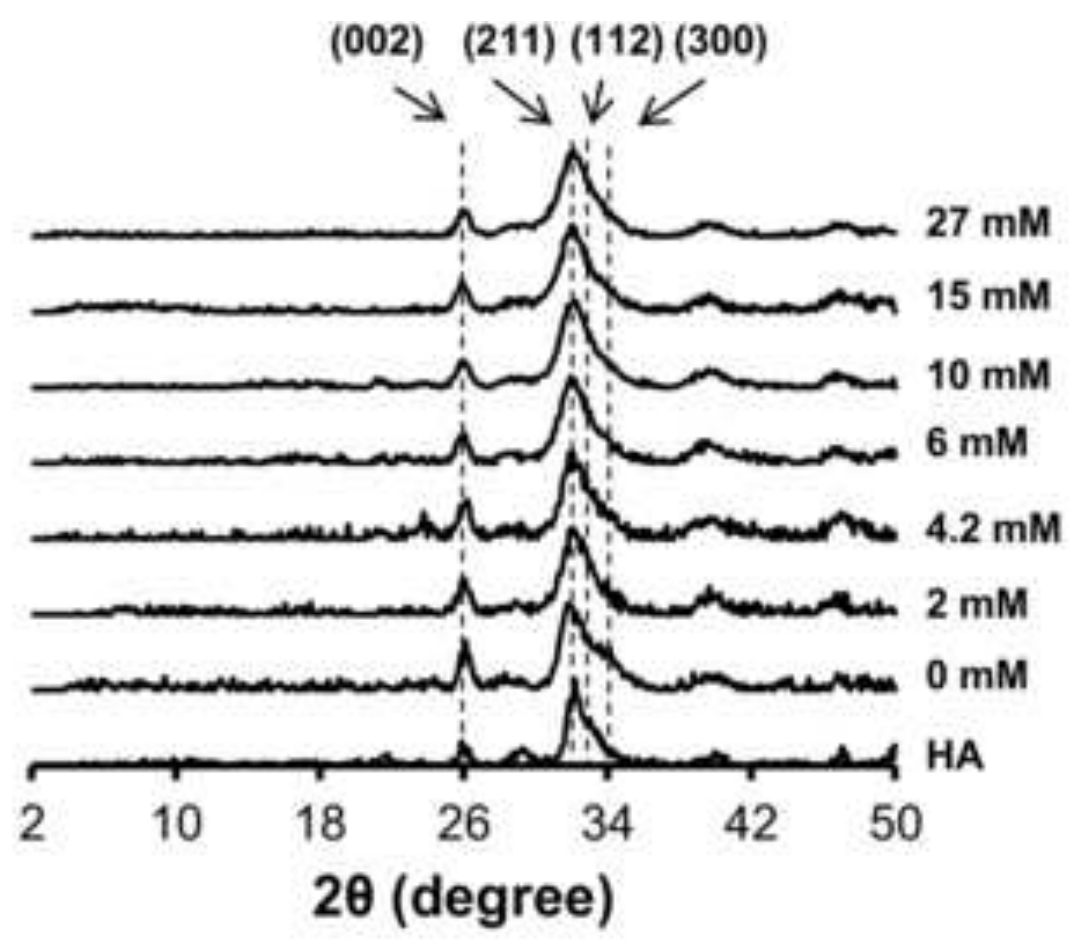

(c)

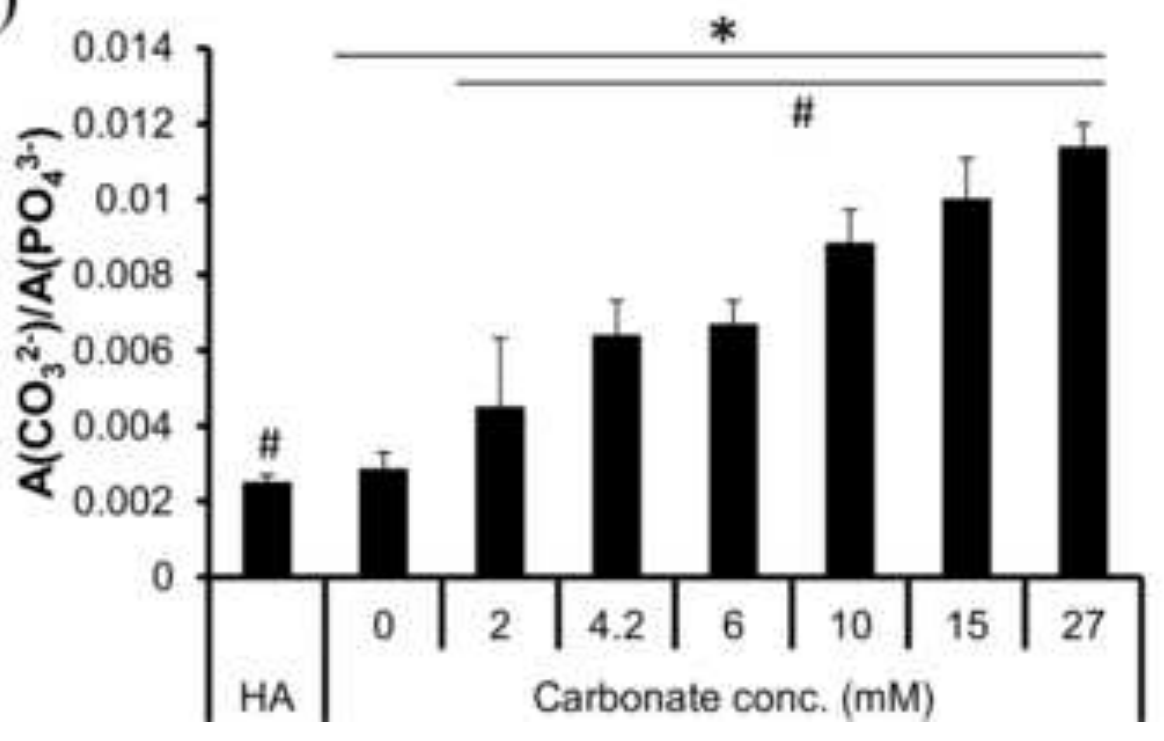

(b)

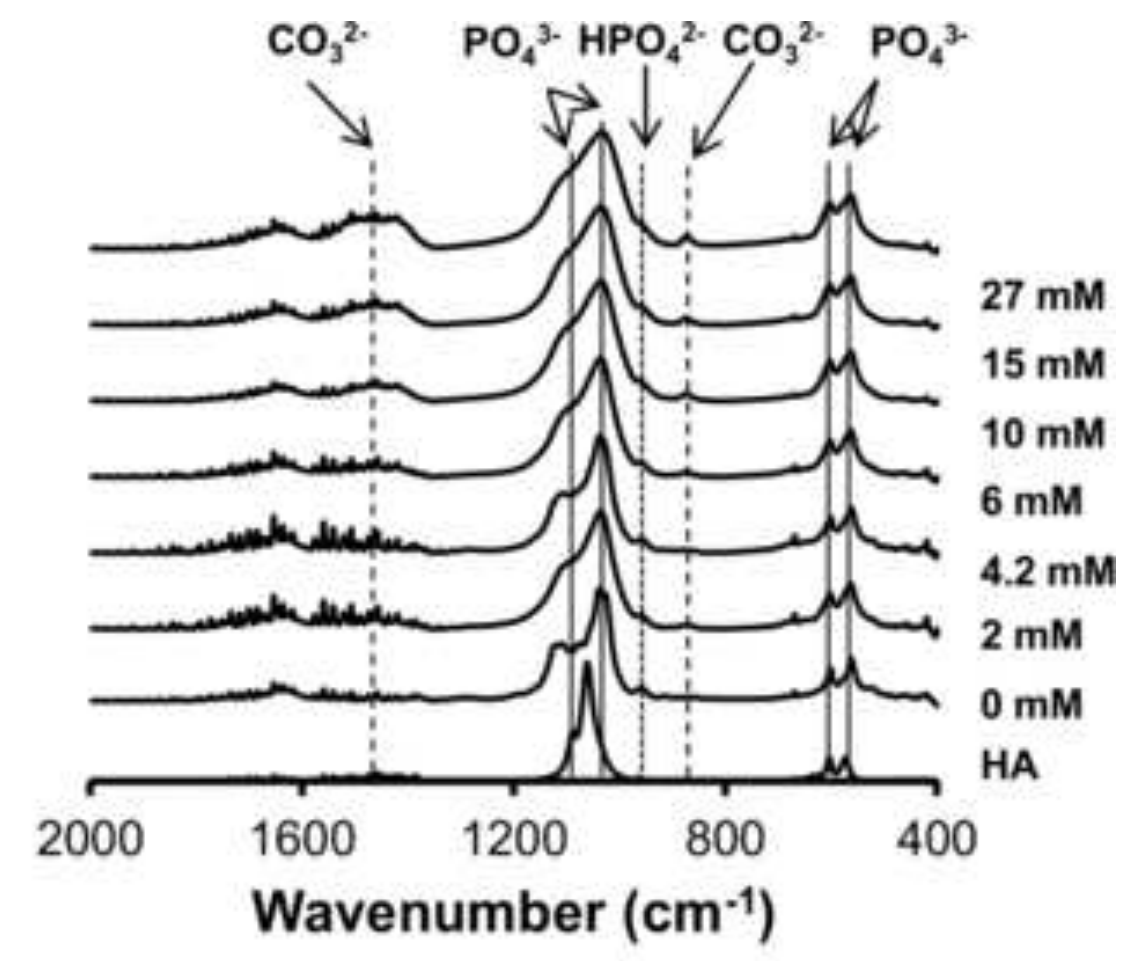

(d)

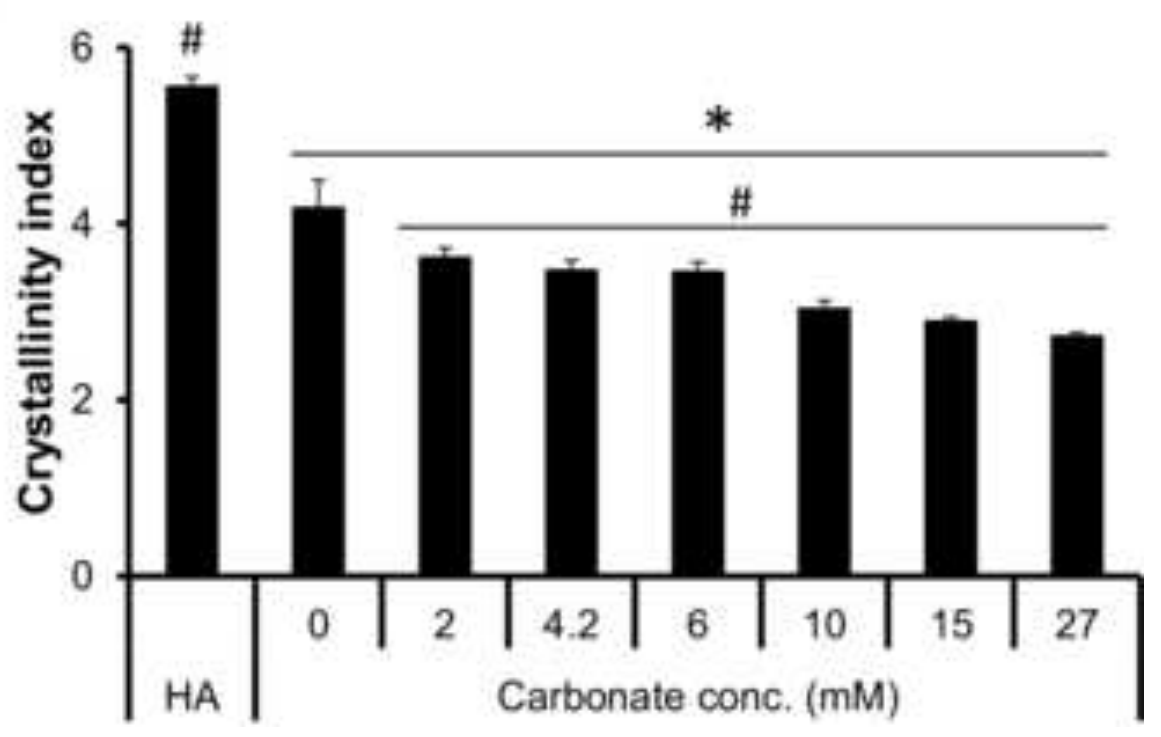



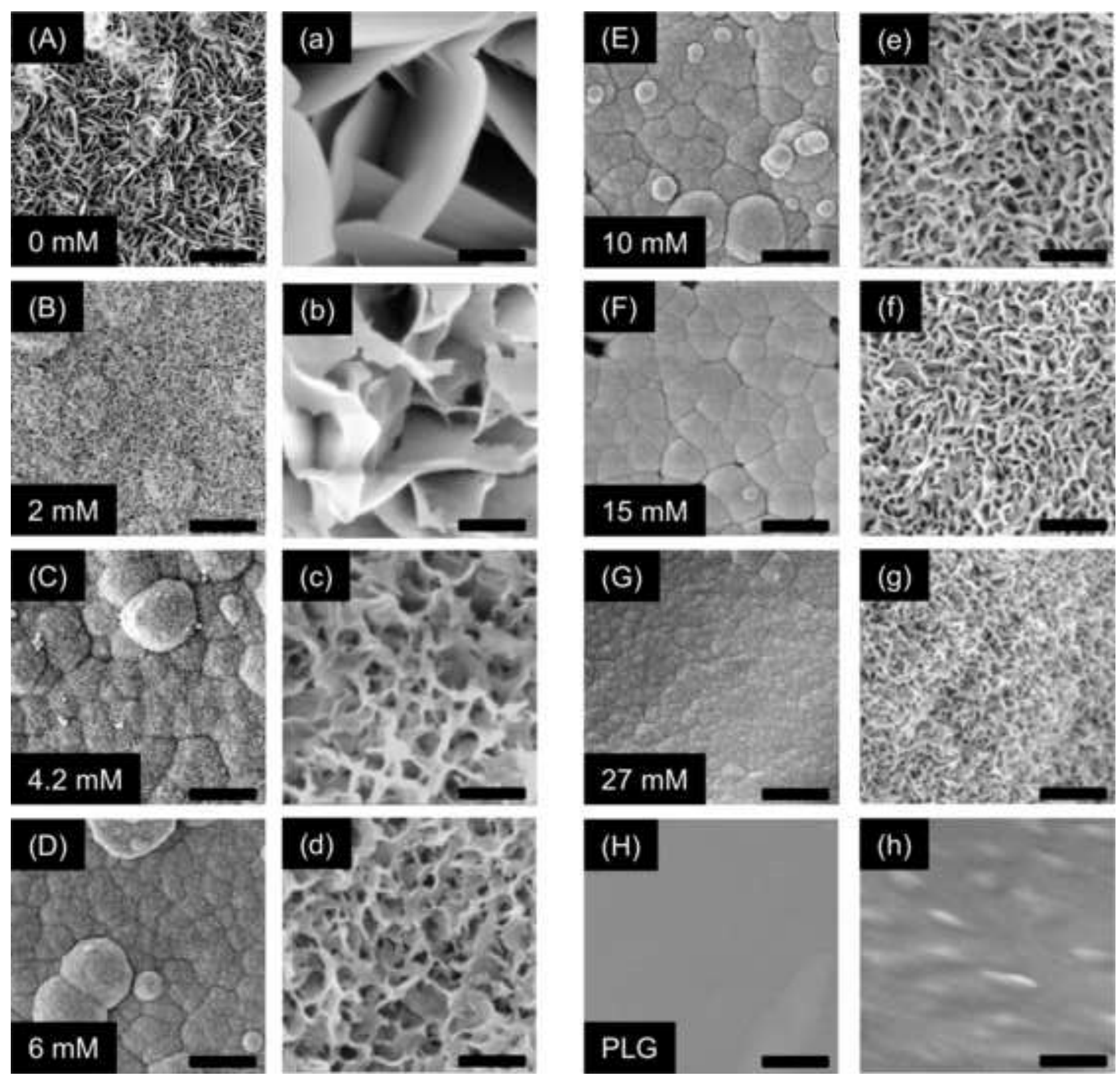
(a)
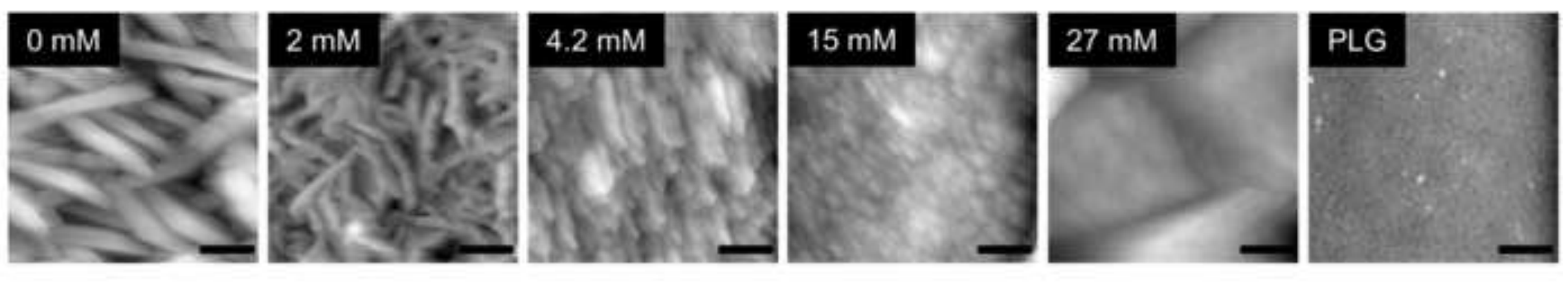

(b)

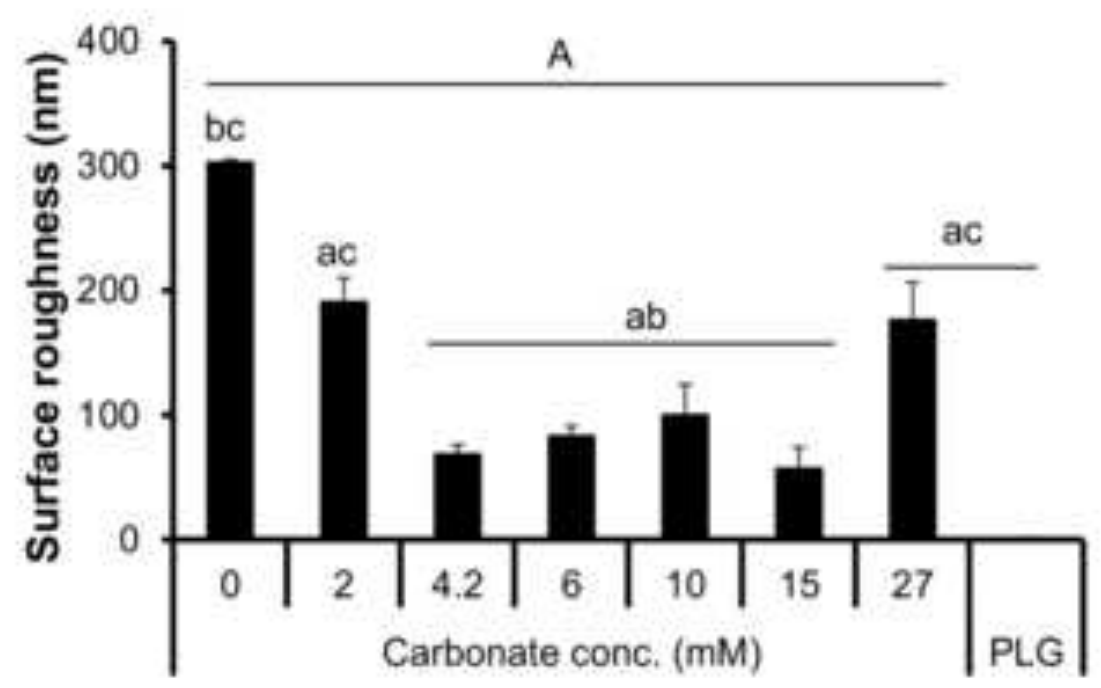

(c)

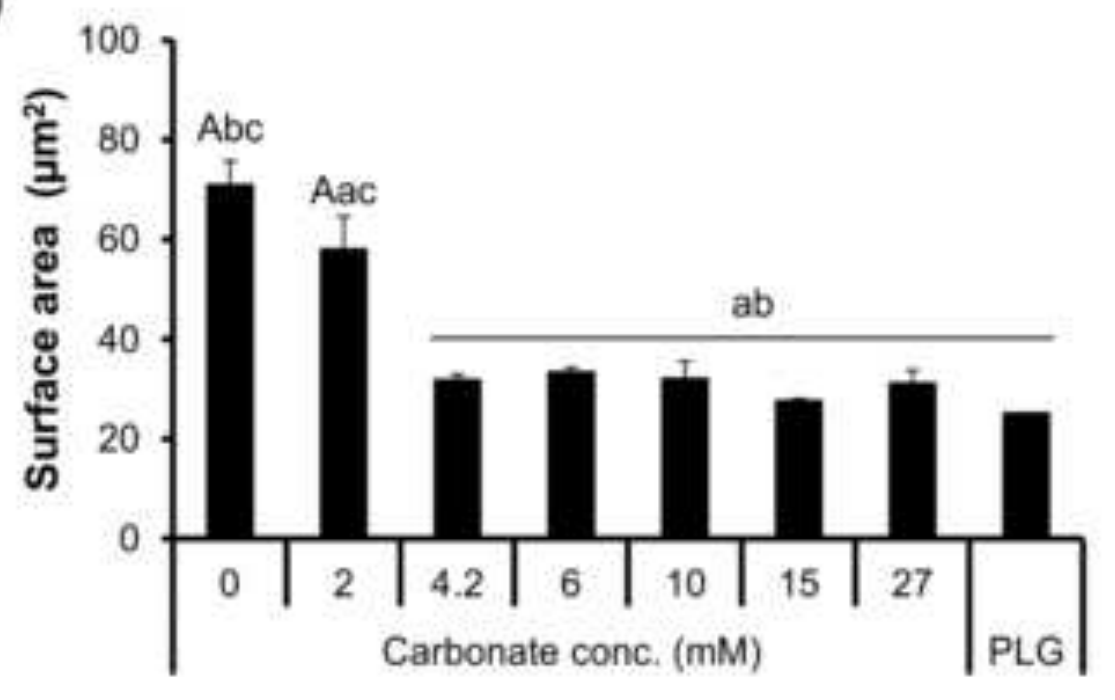


(a)

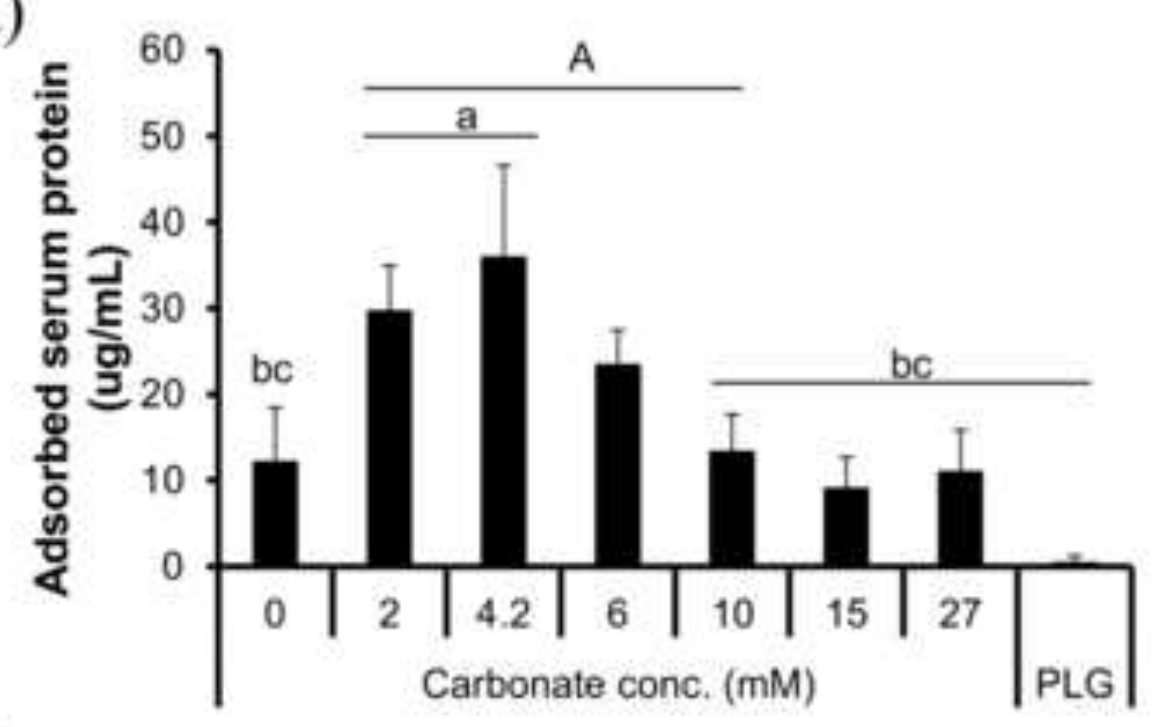

(b)

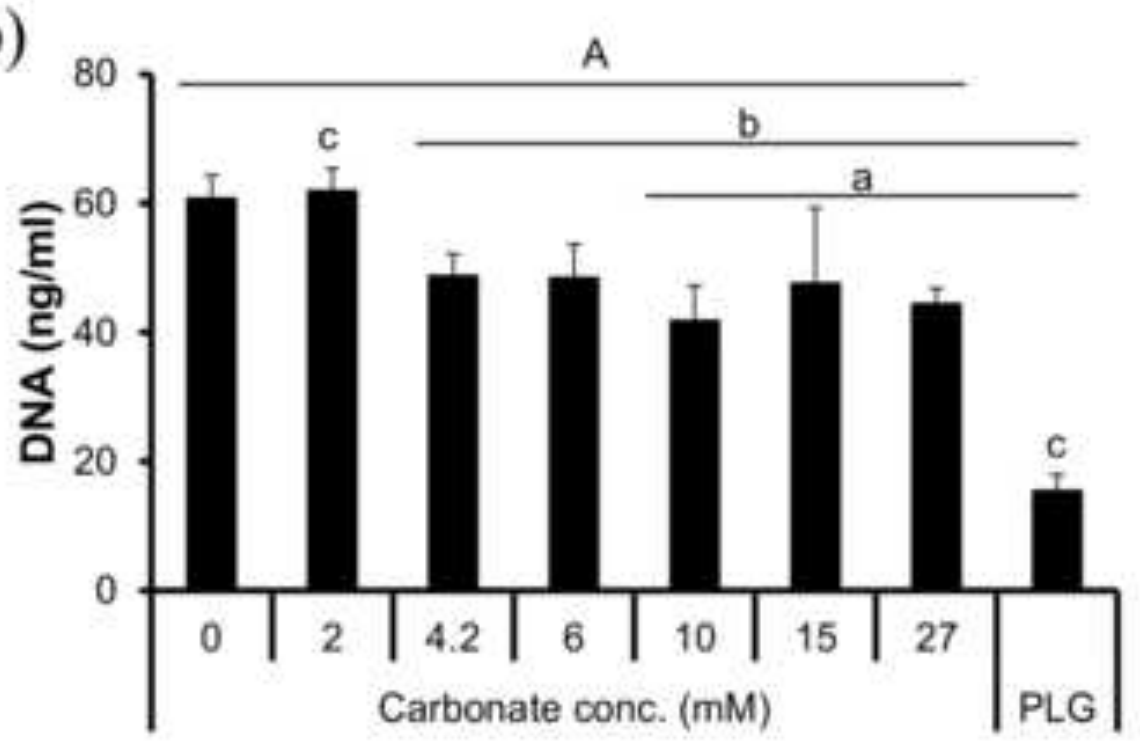

(c)

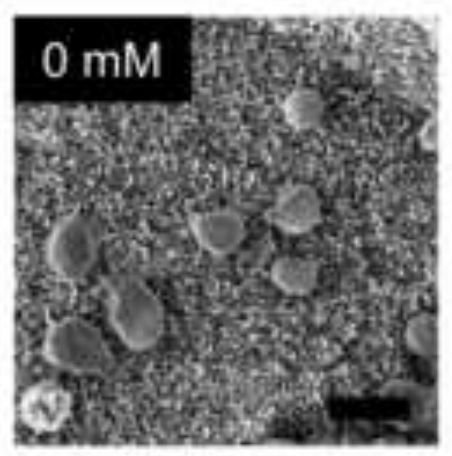

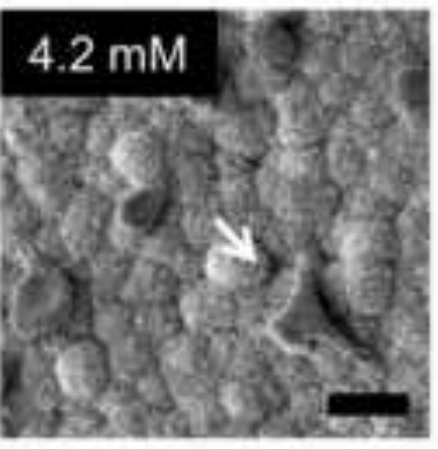
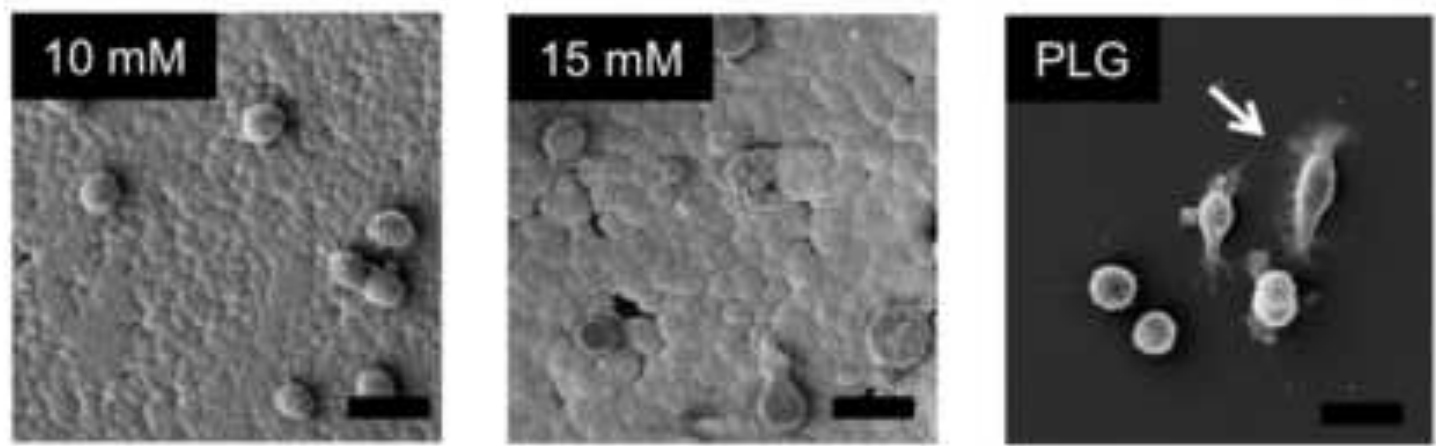
(a)

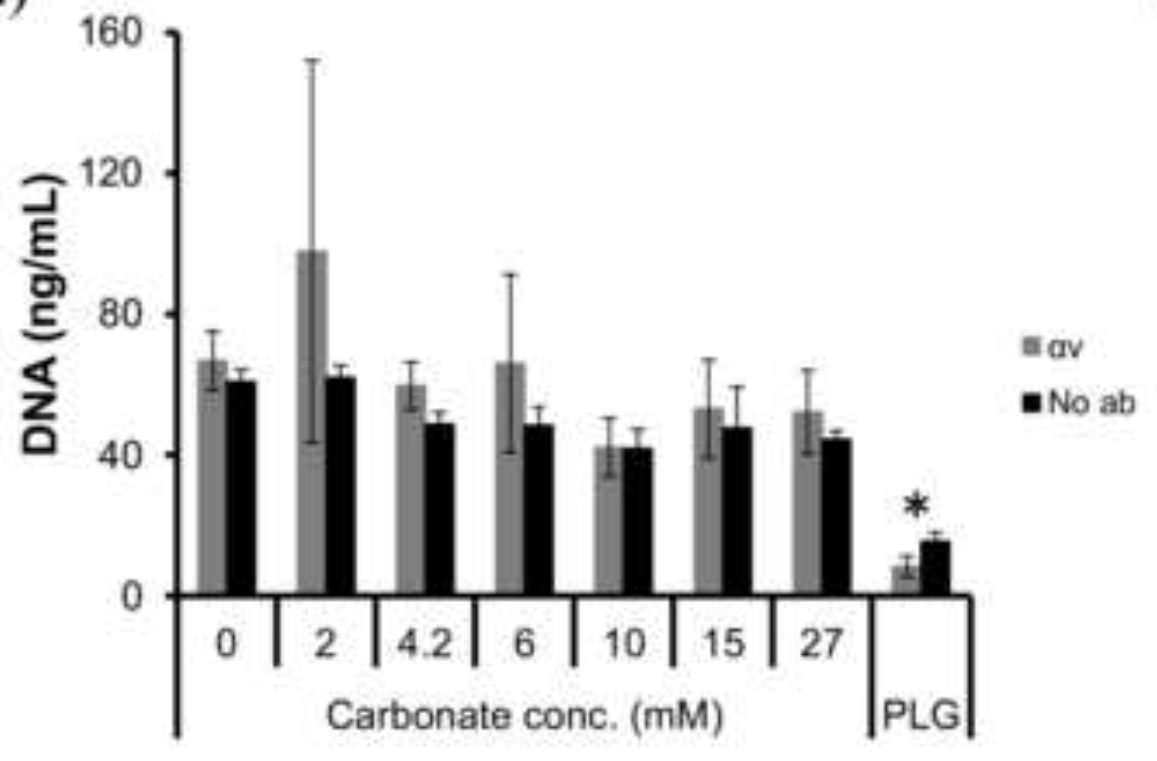

(b)

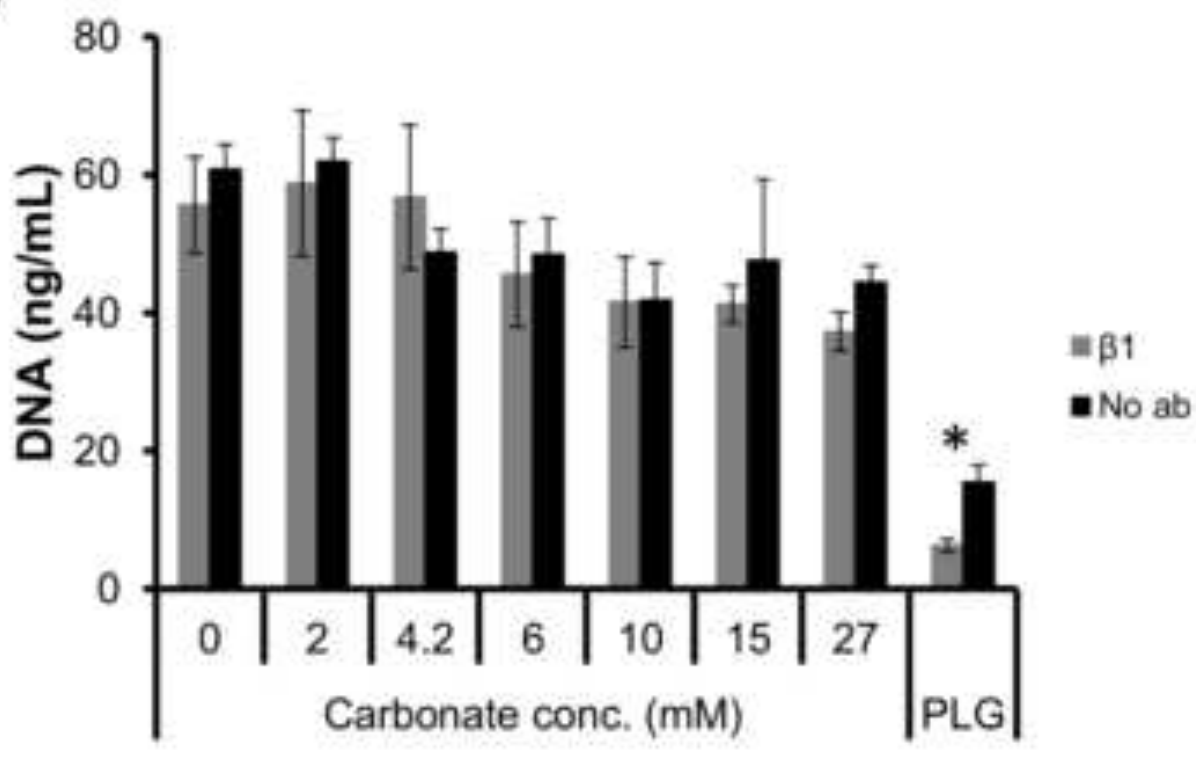


(a)

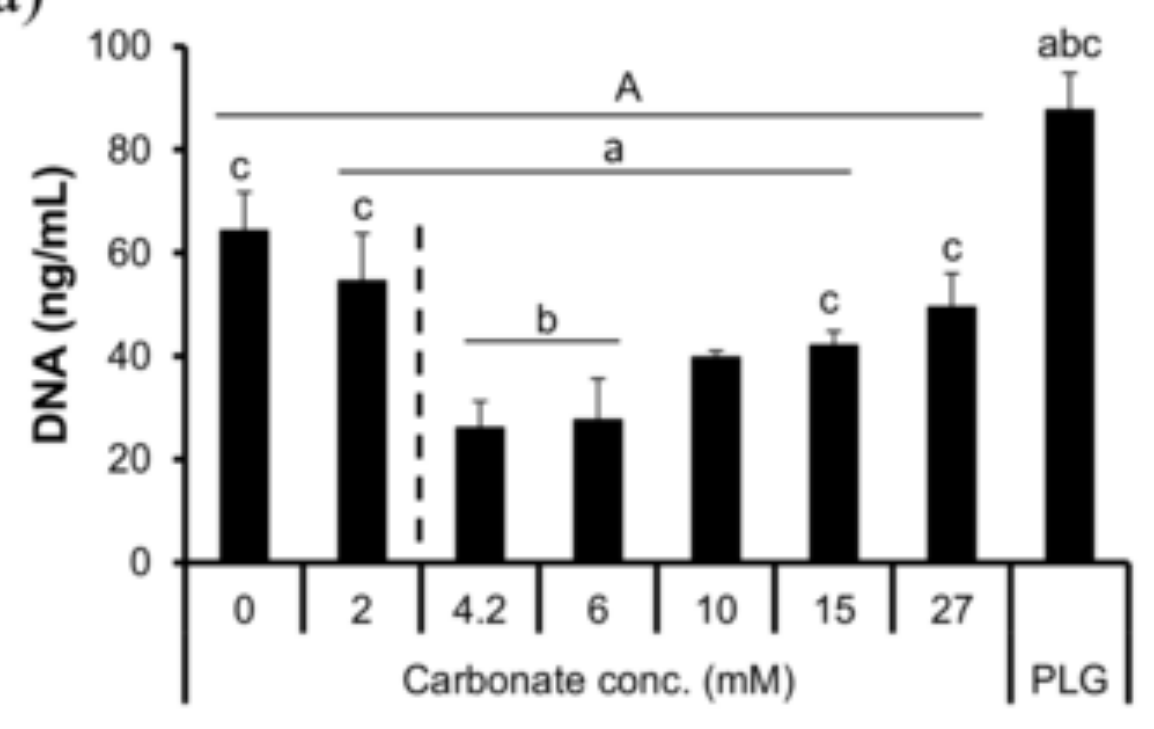

(b)

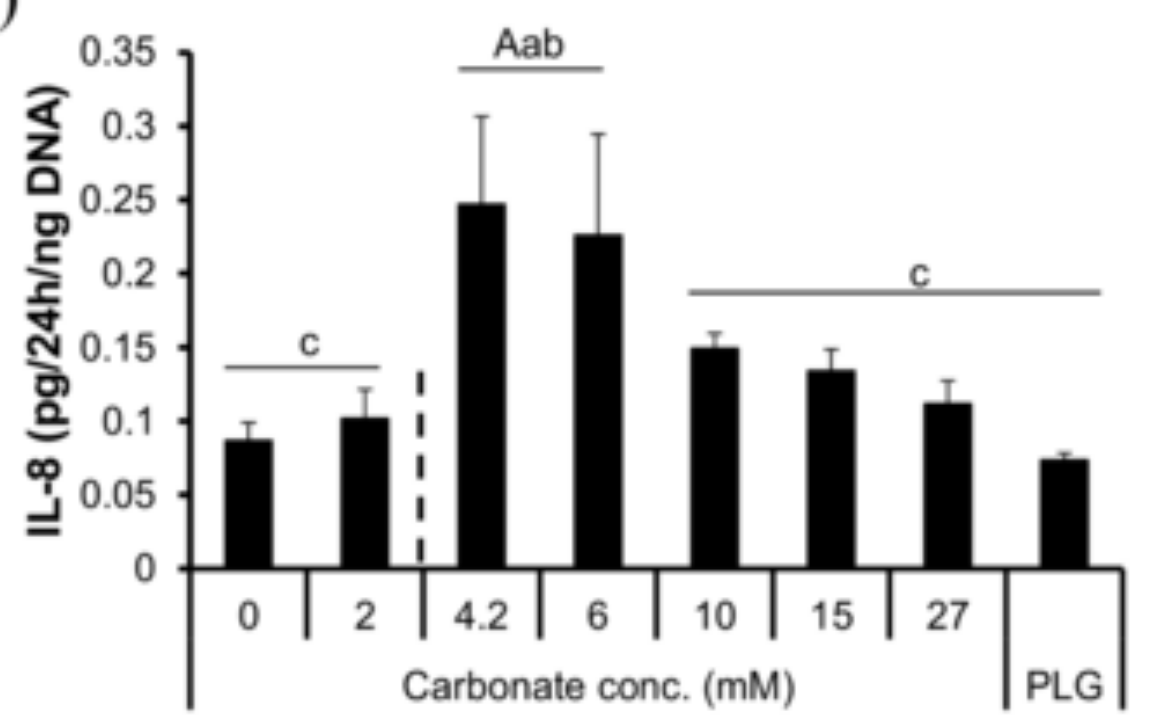


(a)

$$
\square P L G=0 \mathrm{mM}=4.2 \mathrm{mM} \square 15 \mathrm{mM}
$$

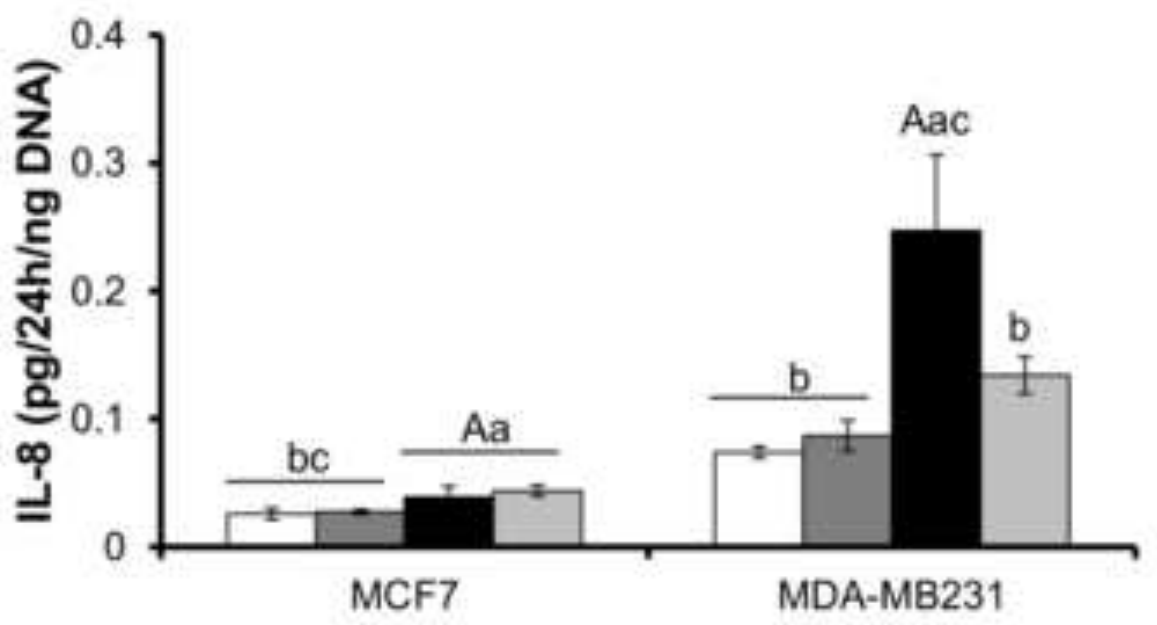

(b)

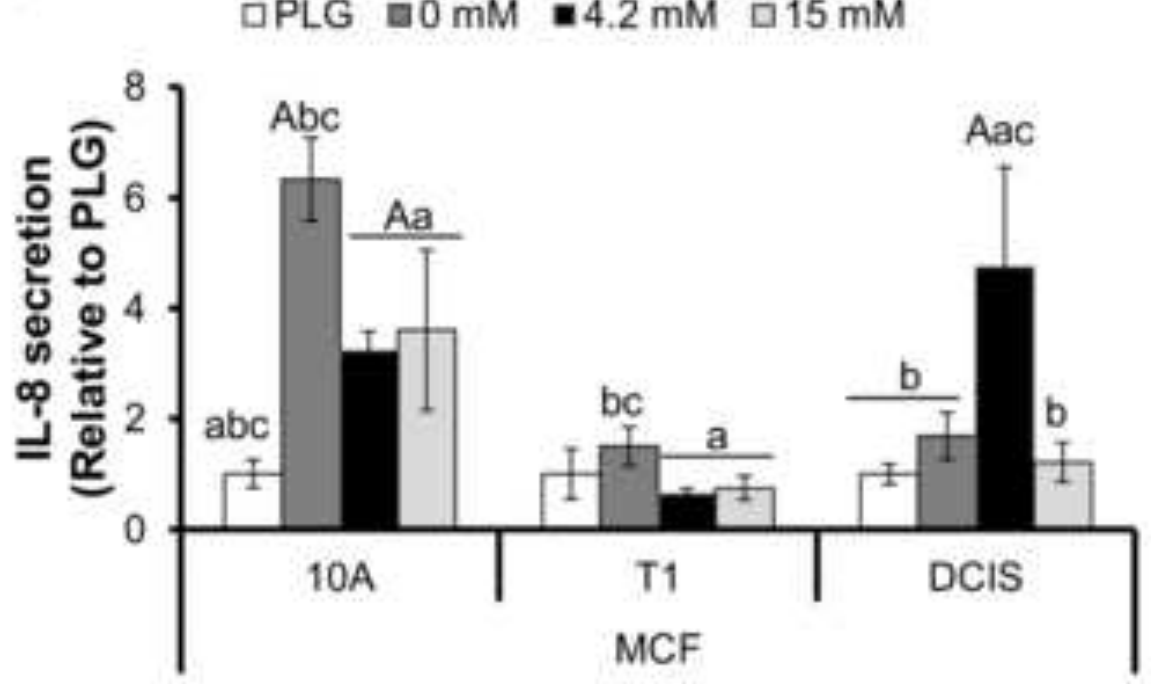


Table. Composition of ions in blood plasma and SBF solutions

\begin{tabular}{|c|c|c|c|c|c|c|c|c|c|}
\hline \multirow[b]{2}{*}{ Ion } & \multicolumn{8}{|c|}{ Concentration (mM) } & \multirow[b]{2}{*}{$\mathrm{pH}$} \\
\hline & $\mathrm{Na}^{+}$ & $\mathrm{K}^{+}$ & $\mathrm{Mg}^{2+}$ & $\mathrm{Ca}^{2+}$ & $\mathrm{HPO}_{4}{ }^{2-}$ & $\mathrm{SO}_{4}^{2-}$ & $\mathrm{Cl}$ & $\mathrm{HCO}_{3}^{-}$ & \\
\hline Blood plasma & 142 & 5 & 1.5 & 2.5 & 1 & 0.5 & 103 & 27 & 7.4 \\
\hline Simulated Body Fluid & 142 & 5 & 1.5 & 2.5 & 1 & 0.5 & 148.8 & 4.2 & 7.4 \\
\hline Modified SBF & 145.2 & 6 & 1.5 & 5 & 2 & 0.5 & $134.2-161.2$ & $0-27$ & 6.8 \\
\hline
\end{tabular}


Gerbonated hydroxympinte formation

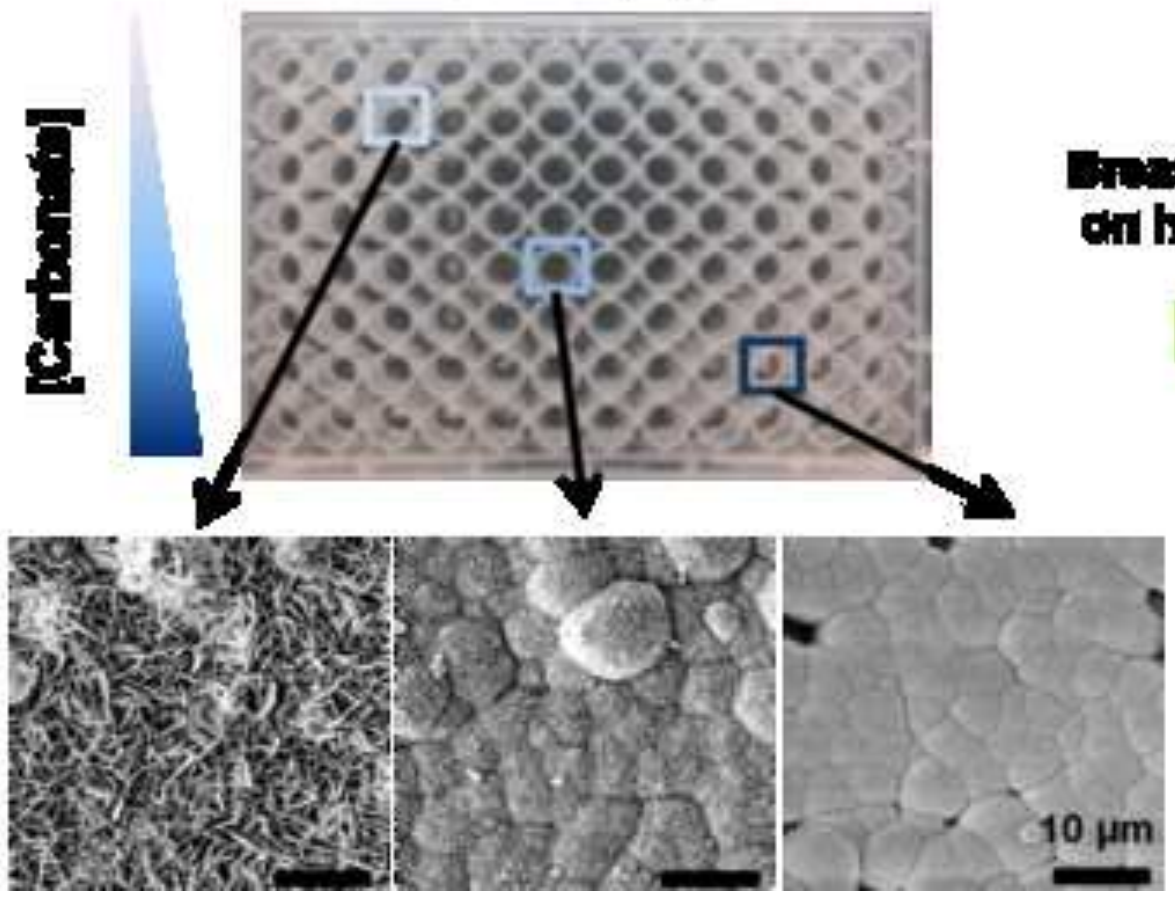

\section{Braest ceneer cell hiternetions}

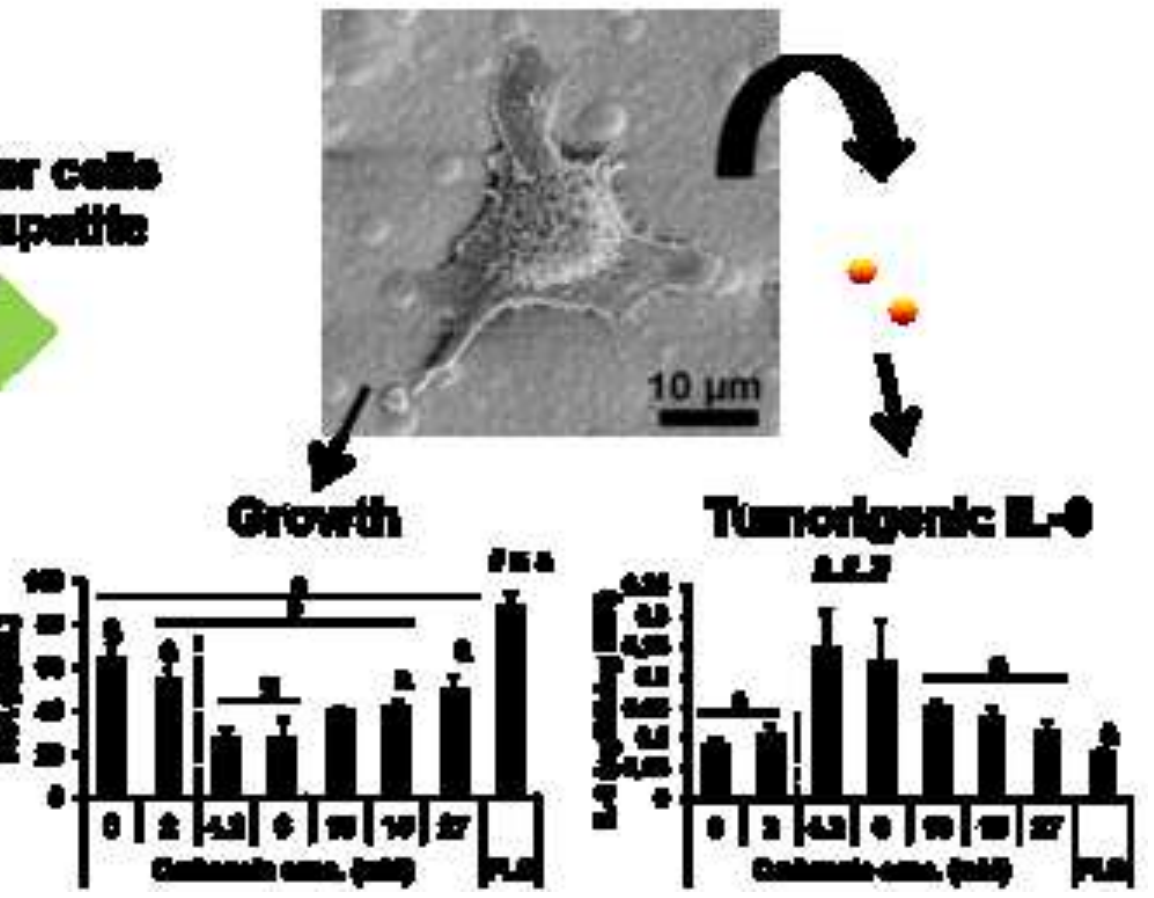

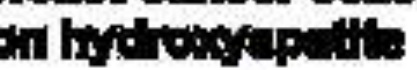

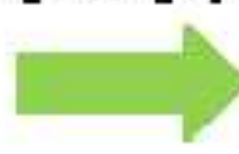

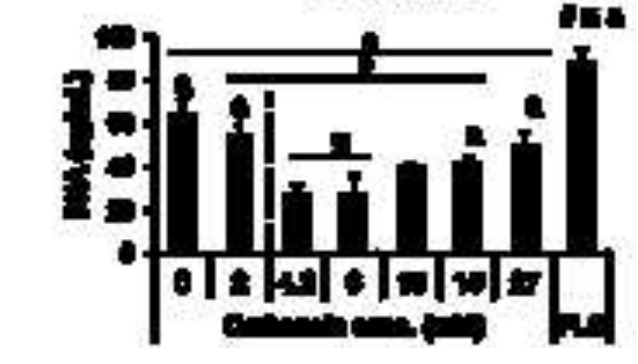

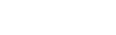

